UCID-21179

\title{
Thermal Damage Study of Beryllium Windows Used as Vacuum Barriers in Synchrotron Radiation Beamlines
}

\author{
F. R. Holdener, G. L. Johnson, \\ V. P. Karpenko, and P. K. Wiggins \\ Lawrence Livermore National Laborai sy \\ J. A. Cerino, M. T. Dormiani, and B. P. Youngman \\ Stanford Synchrotron Radiation Laborato"y \\ E. W. Hoyt

\section{Stanford Linear Ascelerator Center}

September 17, 1987

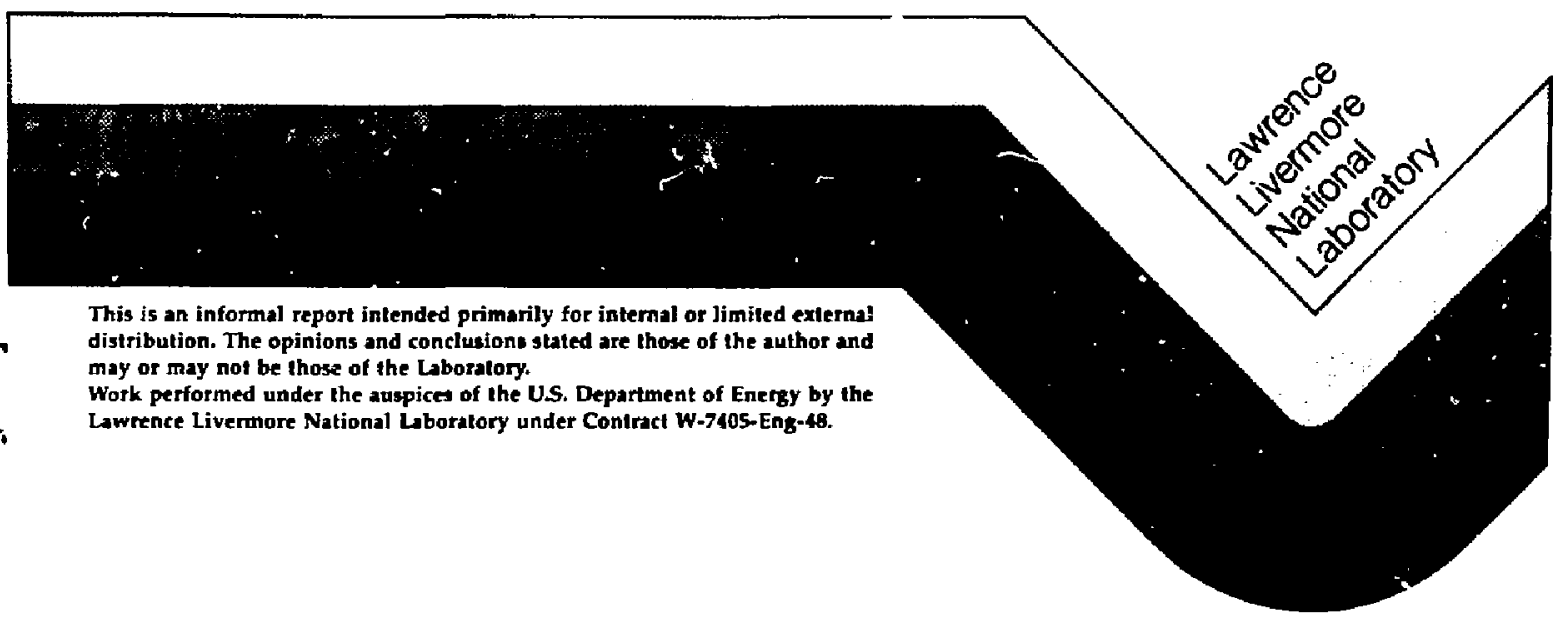




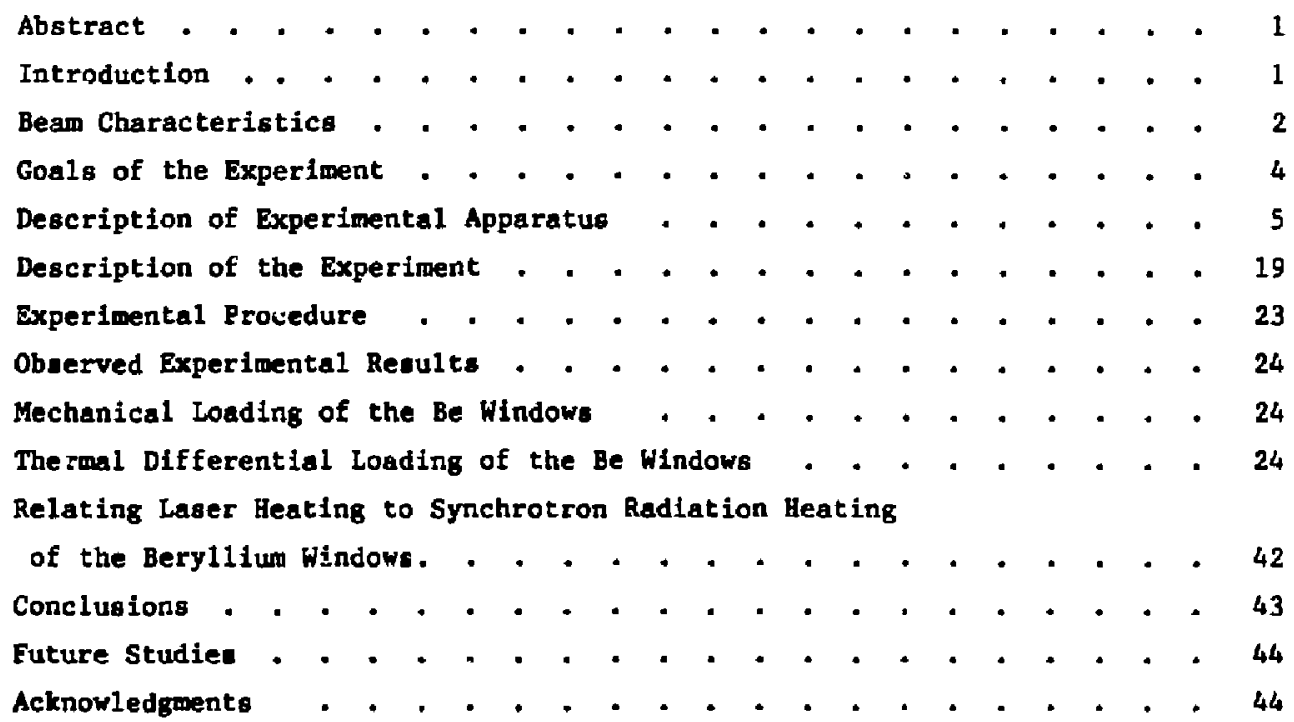

\section{DISCLAIMER}

This repont was prepared

Government. Nerither the an account of wort

employes, makes any we United Slates Government not any an agency of the United States pility for the socuracy. comply, express or implied, or assumes any thereor, nor any of their ence herein to any or represents that its use wouldess of any information, liability or respansimanufucturer, or specilic commercial product pot infringe privalely oparatus, product, or mendation, or for herwise does not necesuct, process, of semice by irade ned rights. Referand opinions of aroring by the United Slates Gonstitute or imply its endore, trademark. United States Governors expressed herein to Government of any agency therement, recom. 
THERMAL DAMAGE STUDY OF BERYLIIUM WINDOWS

USED AS VACUUM BARRIERS

IN SYNCHROTRON RADIATION BEAMLINES

\section{ABSTRACT}

An experimental study to investigate thermal-induced damage to SSRL-deaigned beryllium foil windows was perforwed at LLNL's Laser Welding Research Facility. The primary goal of this study was to determine the threshold at which thermal-stress-induced damage occura in these commonly used vacuum barrlers. An Nd:Yag puleed lacer with cylindrical optics and a carefully designed test cell provided a test environment that closely resembles the actual beamline conditions at SSRL. Tests performed on two beryllium window geometries, with different vertical aperture dimensions but equal foll thicknesses of $0.254 \mathrm{~mm}$, resulted in two focused total-power threaholda at which incipient damage was determined. For a beam spot size similar to that of the Beamline-X Wiggler Line, onset of surface damage for a 5-m by 25-mm aperture window was observed at $170 \mathrm{~W}$ after 174,000 laser pulses (1.2-ms pulse at $100 \mathrm{pps}$ ). A second window with double the vertical aperture dimension (10 mo by $25 \mathrm{~mm}$ ) was observed to have surface cracking after 180,000 laser pulses with $85 \mathrm{~W}$ impinging its front surface. It failed after approximate1y 1,000,000 pulses. Another window of the same type (10 mm by 25 ma) received 2,160,000 laser pulses at $74,4 \mathrm{~W}$, and subsequent netallographic sectioning revealed no igns of through-thickness damage, Cumparison of windows with equal foil thicknesses and aperture dimensions has effectively identifled the hent flux limit for incipient failure. The data show that halving the aperture' vertical dimension allows doubling the total incident power for equivalent onsets of thermal-induced damage.

\section{INTRODtCTION}

Beryllium windows are a key component of beamlines used for synchrotron radiation research. At the present, all but one of the double-cryatal monochromatore at Stanford Syachrotron Radiation Laboratory (SSRL) work in an environment of one atwosphere of helium (He). This necessitates a beryllium (Be) window upetream from the monochromator to isolate the monochromator 
chamber from the electron storage ring which is at $10^{-9}$ Torr. These Be windows limit the photon $f 1 u x$ of the wiggler beamlines in the stanford Positron Electron Accelerator Ring (SPEAR).

Due to concerns of possible Be window failure if the existing calculated $3.75 \mathrm{~W} / \mathrm{mm}$ line-load thermal flux (equivalent to $3.75 \mathrm{~W} / \mathrm{mm}^{2}$ for a 1 -mm beam spot width) window 1 imit is exceeded, there are two $0.254-\mathrm{mm}(0.010-\mathrm{in}$.) thick windows upstream from the monochromator with the interspace filled with argon at $0.5 \mathrm{~atm}$. This interspece is continuously monitored to detect a passible leak from either window. To protect the windows from overheating, graphite filters are intalled upstream from the windows.

At a stored electron energy of $3 \mathrm{GeV}$, the critical energy of the wiggler 1. approximately $7.8 \mathrm{keV}$. This means that half the power emitted from the electrons is at energies less than $7.8 \mathrm{keV}$. The absorption of even $0.025 \mathrm{~mm}$ ( $0.001 \mathrm{in}$ ) of beryllium or carbon is nearly 1002 at energies less than $1 \mathrm{keV}$. Thus, absorbing soft $x$ ray and vacuum ultraviolet (VUV) light with carbon filters protects the Be windowa while transmitting the harder portion of the synchrotron spectrum. Nonetheless, there would be up to $50 \mathrm{z}$ more flux avallable for researchers at $7.8 \mathrm{keV}$ if one could remove both the beryllium and carbon from the beamline. It is desirable to reduce the thickness of existing window designs in order to obtain greater flux throughput. The effort to understand potential causes of Be failure could lead to thinger window designs with the possibility of eliminating one of the two windows in the redundant dauble-window design.

\section{BEAH CEARACTERISTICS}

Beamline- $X$, a wiggler/undulator $x$-ray source presently nearing construction completion at SSRL, has Be window requirements typical of other beamlines at SSRL, E.g., Beamline-VI. The basic Beamline-X optical configuration is shown schematically in Fig. 1, with syatem parameters listed In Table 1, For a 15-period wiggler at 1.3 tesla with 128.7-lim period length and an electron energy of $3 \mathrm{GeV}$ and a critical energy of $7.78 \mathrm{keV}$, the cross section of the source beam is eseentially an elongated ellipe with 2-o (atandard deviation of an ideal Gausaian distribution) dimensions of 0.4 mu by $5 \mathrm{~mm}$. The resulting beam ahape at the Be window is a typical "smile" (see Fig. 1). The smile's basic $2-\sigma$ dimensions are $1.3 \mathrm{~mm}$ by $15.8 \mathrm{~mm}$. 


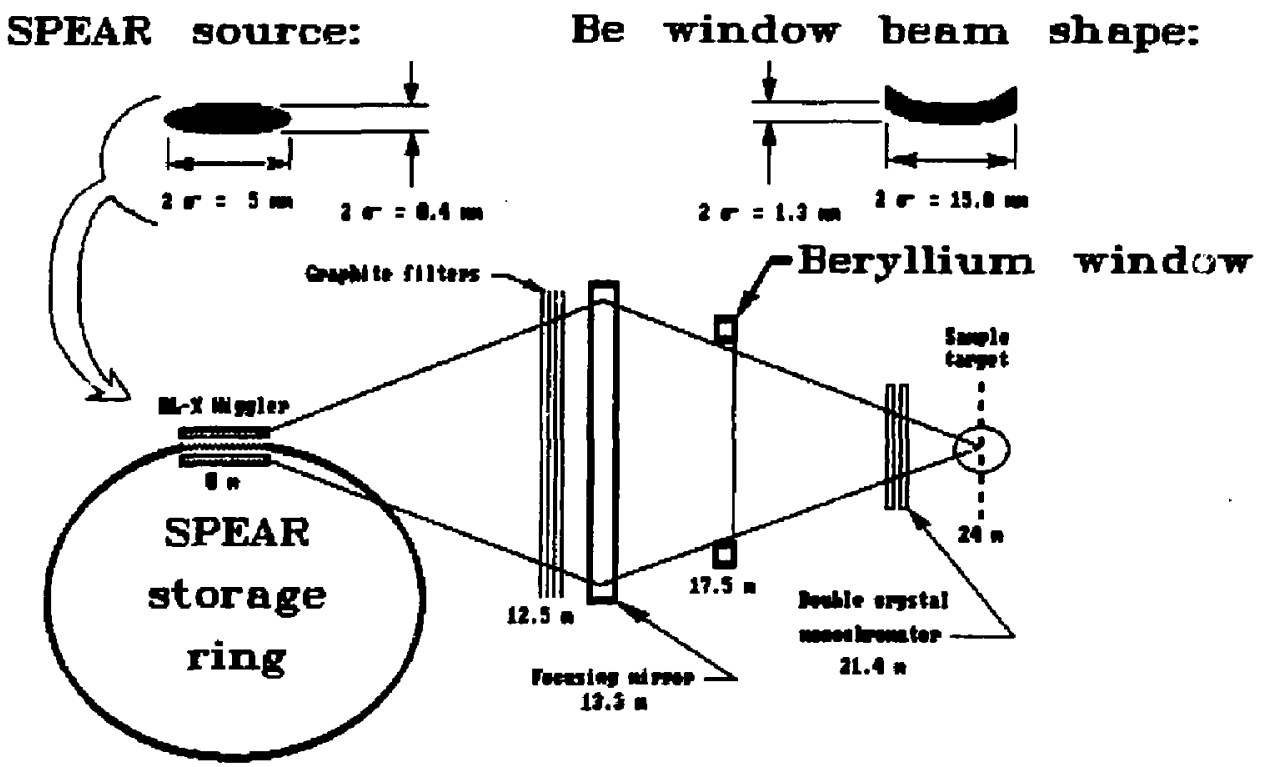

Figure 1. Beamline- $X$ optica configuration with the beam shape at the Be window for wiggler beaniline parametera listed in Table 1. 
Table 1. System parameters for Beamline-X analysis.

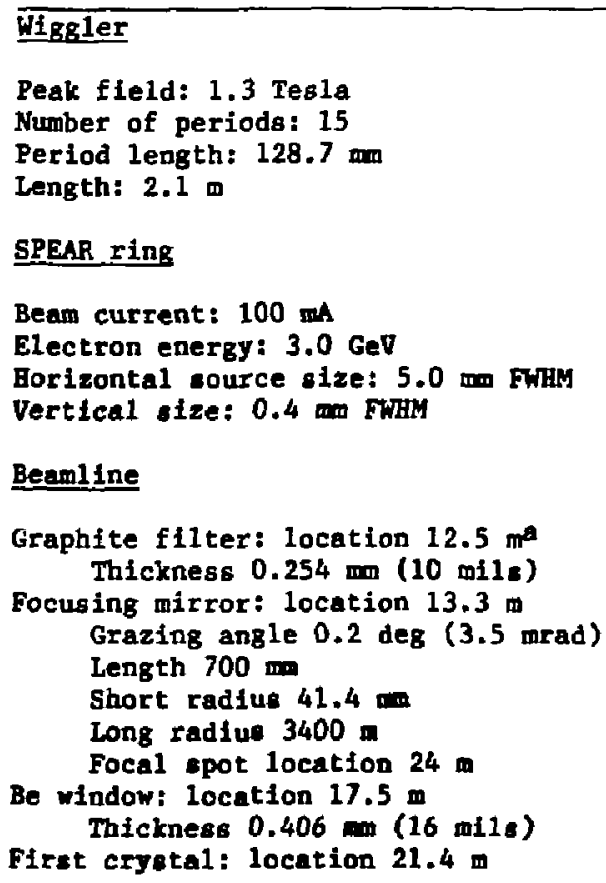

\section{Beamline}

Graphite filter: location $12.5 \mathrm{~m}^{2}$

Thickness $0.254 \mathrm{~mm}$ (10 mils)

Focusing mirror: location $13.3 \mathrm{~m}$ Grazing angle $0.2 \mathrm{deg}(3.5 \mathrm{mrad})$

Length $700 \mathrm{~mm}$

Short radius 41.4

Long radiue $3400 \mathrm{~m}$

Focal spot location $24 \mathrm{~m}$

Be window: location $17.5 \mathrm{~m}$

Thickness $0.406 \mathrm{mom}(16 \mathrm{mils})$

First cryotal: location $21.4 \mathrm{~m}$

\section{acomponent location is relative to the wiggler center.}

GOALS GF THE EXPERIMENT

The experimental goale of this atudy are to:

1. Simulate beamiline conditions in a leser thermal cycling test atup for Be windowe.

2. Quantify the number of laser pulses and the beam power level (i.e.. beam energy density per unit time) for the onset of window damge. Onset of window damage is defined as a visually detectable change in surface characteriatica.

3. Identify the beam power level and number of pulses where window failure occurs. Fatlure is defined as perforation of the window, allowing gas exchange or loss of formard chamber vacuum. 
4. Ascertain the mode of window failure and understand what metallurgical or structural flaws account for failure.

\section{DESGRIPTION OF EXPER IMENTAL APPARATUS}

SSRL provided the beryllium windows for the thermal damage study performed at LLNL's laser Helding Facility. The windows were fabricated by Electrofusion (Fremont, Californis) per SSRL specifications. The two window types tested, both 0.254-mm thick, have apertures of $5 \mathrm{~mm}$ by $25 \mathrm{~mm}$ and $10 \mathrm{~mm}$ by $25 \mathrm{~mm}$, respectively. The window aperture is oriented in this test the same way $a s$ in Beamline-x, i.e., with the long dimension of the window on the horizontal and the Be foil normal to the incident beam axis. The beryllium foil is vacuum brazed into a copper heat sink (see Fig. 2). The heat sink has a 5-mm stainless steel tube soldered into a groove on its perimeter for water cooling. The Be window is mounted at the beam exit side of the copper aperture. The high-purity beryllium (grade IF-1 consisting of $99.87 \mathrm{Be}$ ) is produced by extruding and hot rolling beryllium ingots cast from vacuum-melted, electrolytically refined beryllium flakes.

The Be window assembly is mounted into a special test cell shown schematically in Figs. 3 and 4 . The Be foil separates the test cell into two chambers, each of which may be independently pressurized or evacuated. The forward chamber provides space between the Be window and the sapphire window lager beam inlet port. The rear chamber extends from the Be window to the rear sapphire window at the observation port. Each chamber is sealed to the Be window assembly by 0 -ring seals and fitted with a line to which a vacuum pump and a gas pressure source (argon or heiium) are connected. Both chambers are monitored with a vacuum transducer and a pressure gage.

The laser beam source is a Raytheon Model SS-501-A7 Precision Welder/Driller. Specific parameters of this unit are given in Table 2. The workpiece table moves in the $x-y$ or horizontal plane. The laser beam exit aperture moves in the $z$ or vertical axis. The workpiece table and the laser beam head movement are accurately positioned by computer numerical control (CNC) with accuracy of $c=0.003 \mathrm{in}$. The test cell, calorimeter, infrared camera, and vacuum/pressure valves and vacuum gages are mounted on the $x-y$ table (see Figs. 5 through 7). Each piece of equipment is assigned an $x-y-z$ set position with the CNC system for easy realignent. 


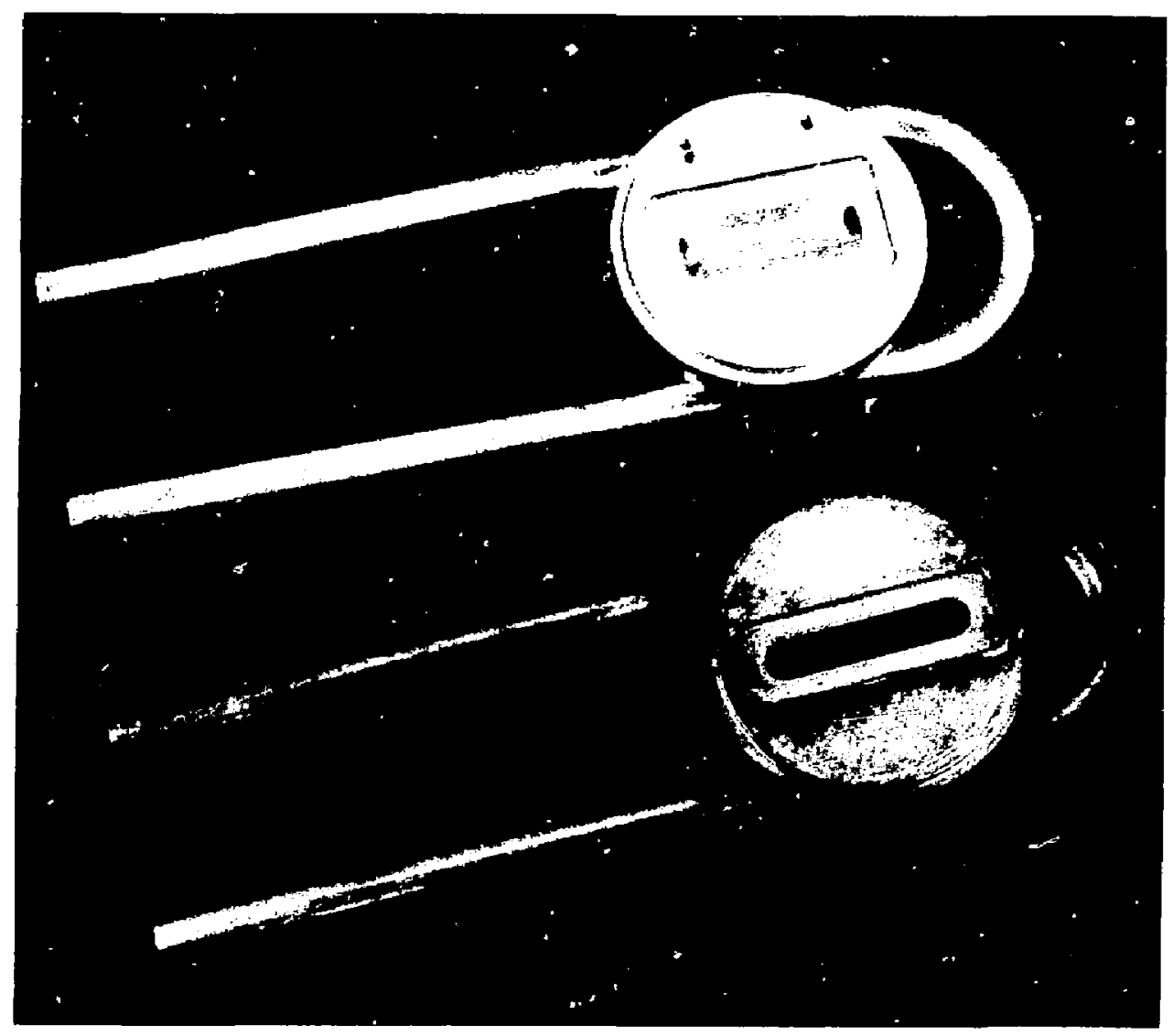

Figure 2. Beryllium window assemblies consisting of $0.254-m m$ beryllium foil vacuum brazed into a copper heat sink that has a 5 -mm stainless steel tube soldered into its perimeter groove: (a) 10-man by 25-mim aperture shown with Be foil mounted, (b) 5-mm by $25-m m$ aperture with Be foil removed. 


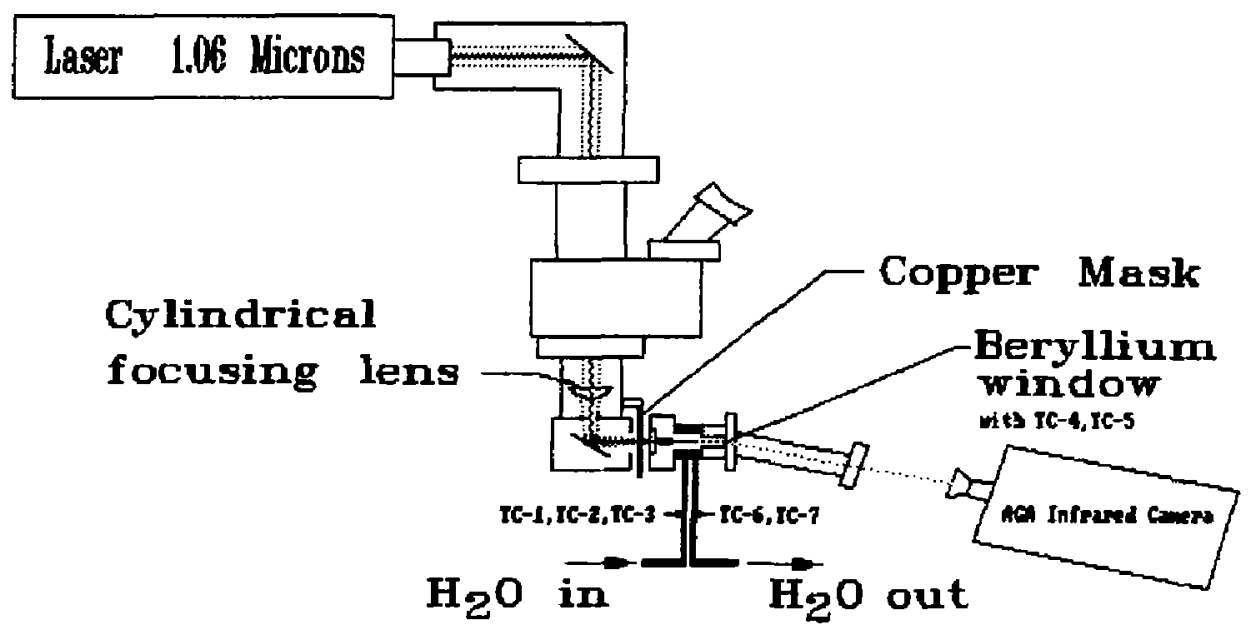

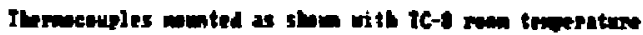

Figure 3. Laser-impinged beryllium window thermal test schematic showing key components: AGA infrared camera, spectral range of 3 to $6 \mathrm{\mu m}$; thermocouples; cylindrical focusing lens, uncoated fused silica, 150-m focal length; laser parameters are listed in Table 2. 


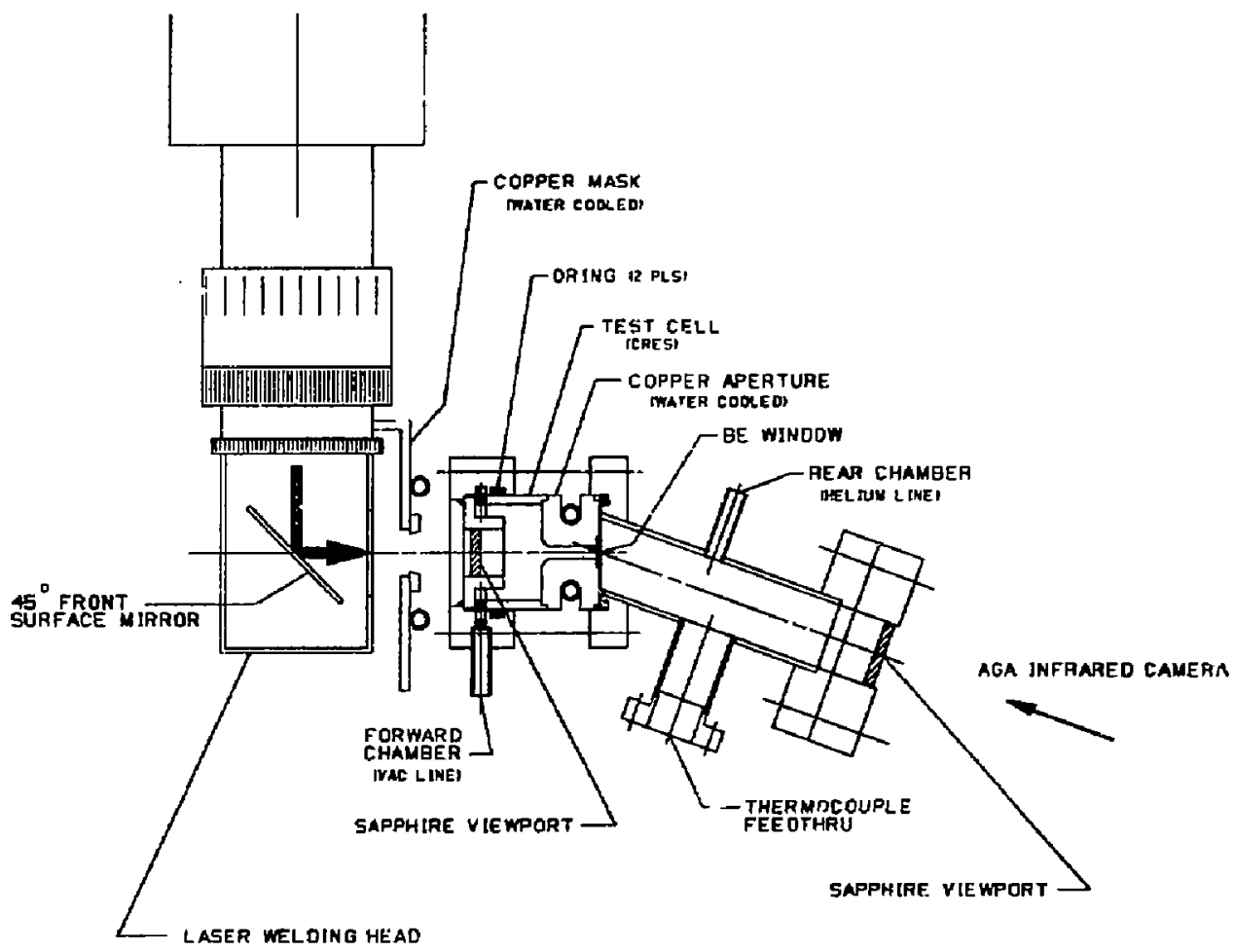

Figure 4. Beryllium window test cell schematc showing detailed cross section. 


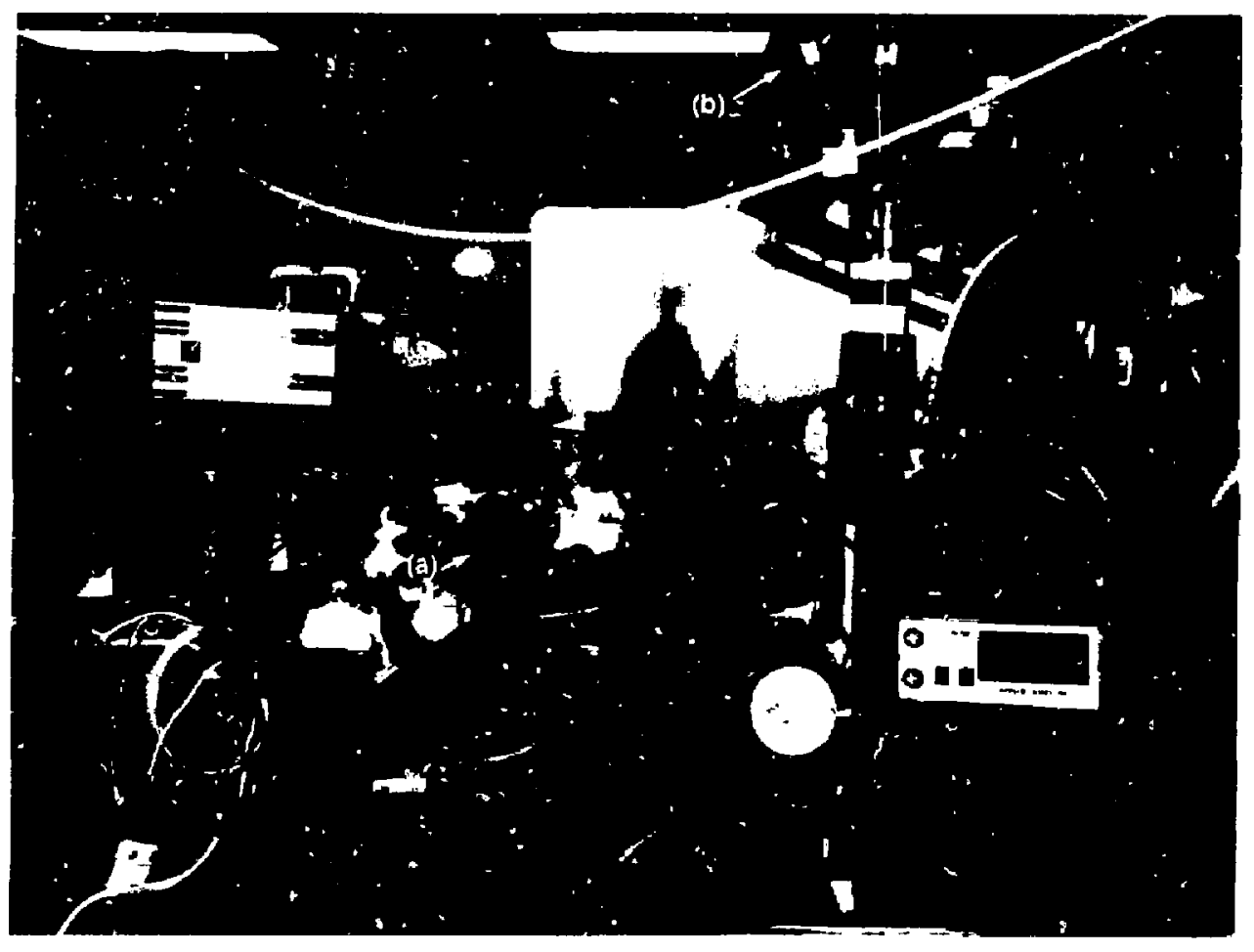

Figure 5. Photograph of actual Be window test setup showing: (a) front view of test cell, (b) Nd:Yag laser source and associated diagnostics. 


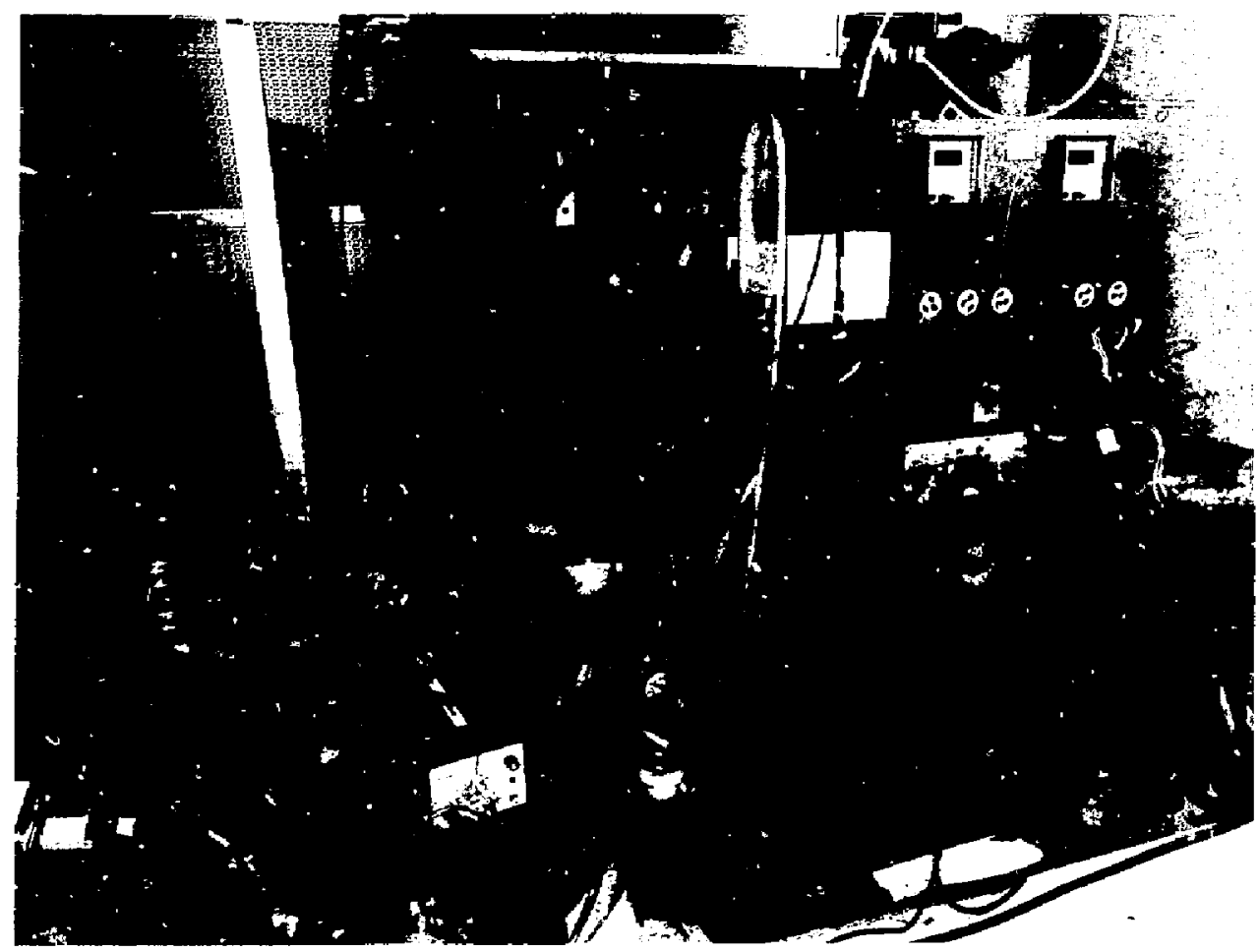

Figure 6. Photograph of Be window test setup showing vacuum pump, water flow system and associated controls. 


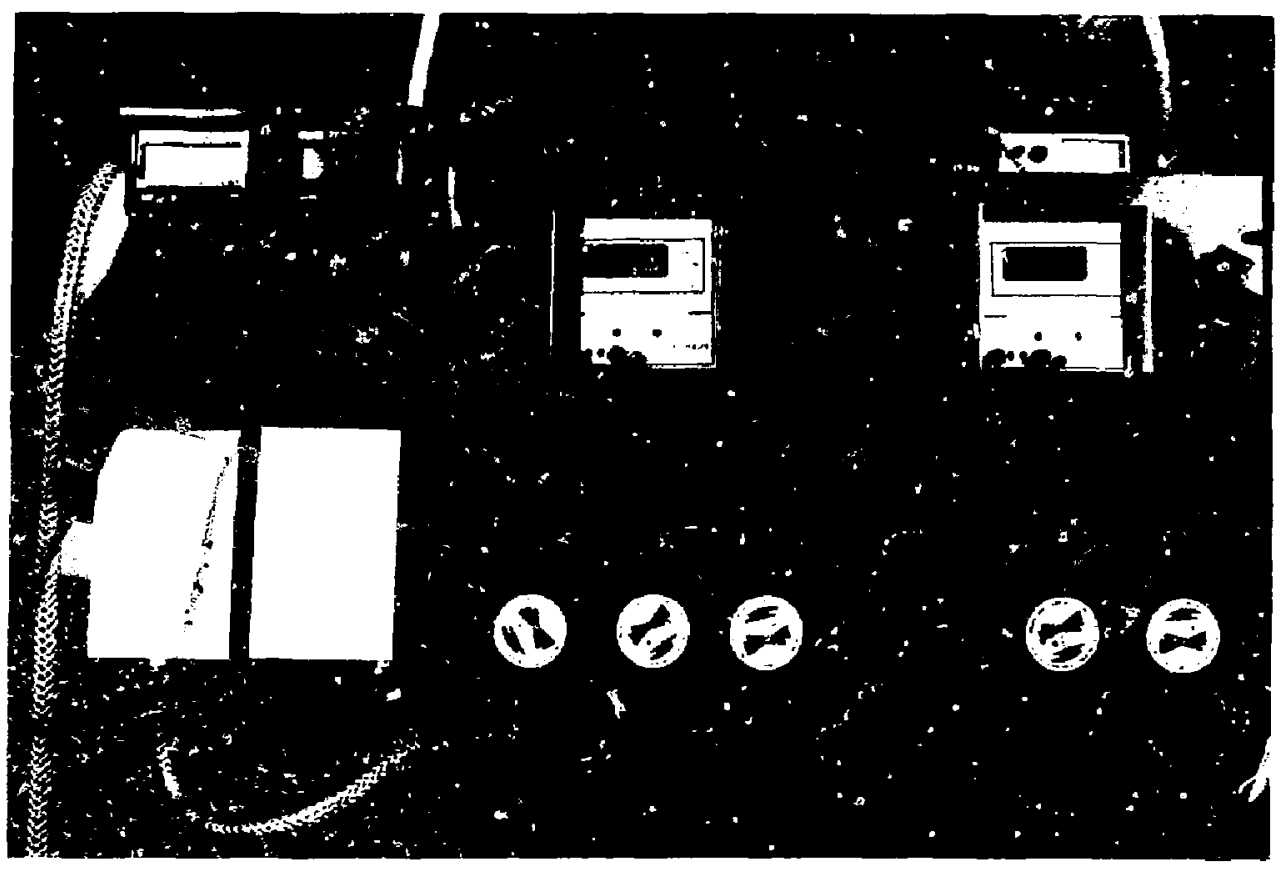

Figure 7. Photograph of Be window test control panel with vacuum-to-pressure controls and associated readouts. 
Table 2, Parameters of Raytheon Model SS-501B-h7 precision welder/driller.

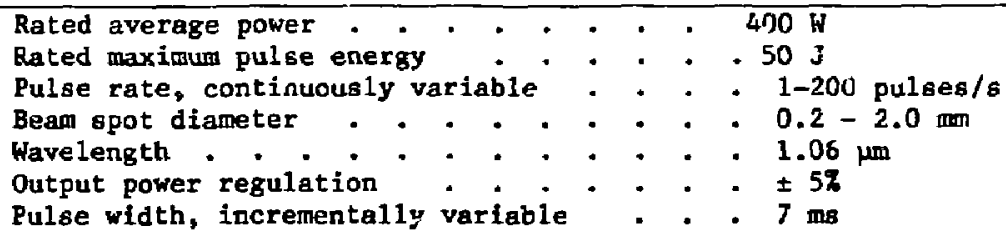

For all tests the pulse width was set at $1.2 \mathrm{~ms}$ and the pulse rate was set at 100 pulses/s. A pulse-forming network adjusts the total energy stored per pulse and thus the laser power output. The spherical focusing lens normslly used for welding/drilling operations was replaced with an uncoated 150-nith cylindrical fused silica lens. The lens focises the laser beam in the vertical direction, closely approximating the actual synchrotron wiggler beam apot size but withou', the characteristic smile resulting fror the actual beamline cylindrical mirror. The beam is reflected horizontally with a 45-degree front surface mirror and then passes through a water-cooled copper mak that removes the outer beam edges producing the desired beam dimensions. The laser beam then passes through the test chamber's frovt sapphire window and onto the Be window surface.

A target block is mounted to the side of and in the same plane as the Be window in order to check the beam spot size attained. Exposed photographic paper mounted to the target block was burned with the laser beam to document the actual spot size and shape on the Be foil (Bee Fig. 8 for examples of beam burns).

An AGA Thermovision 780 infrared camera system monitored the relative temperature gradients and heat flow patterns on the back of the Be through the observation port. The camera uses a shortwave scanner sensitive to the 3.0-to-5.6 $\mu$ spectral band. Figure 9 shows typical outputs in color-band gradients of windows $2 A$ and $2 B$. Besides verifying laser beam centering, the AGA camera also gives a rough definition of the temperature gradients on the window. To interpret the camera output of Fig. 9b according to the AGA camera operations manual, one adds the thermal level setting (in this case 40 isothermal units) to the color band reading (e.g., white marker at 0.10 ) timed the thermal range (set in this case at 500). The result, $40+(0.1 * 500)=90$ isotherm units, yields a temperature of $145^{\circ} \mathrm{C}$ from the calibrated curve in Fig. 10. In this manner temperaturea can be obtained at any location on the window. 


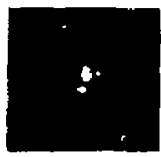

(a)

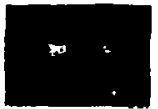

(c)

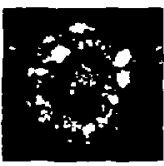

(b)

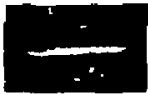

(d)

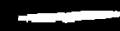

(e)

Figure 8. Actual beam burns of exposed photographic paper with 10 laser pulses for 0.1-s shutter duration: (a) unfocused beam at $100 \mathrm{~W}$, (b) unfocused beam at $200 \mathrm{~W}$, (c) semi-focused beam at $100 \mathrm{~W}$, (d) Focused beam at $100 \mathrm{~W}$, (e) focused beam at $200 \mathrm{~W}$. 


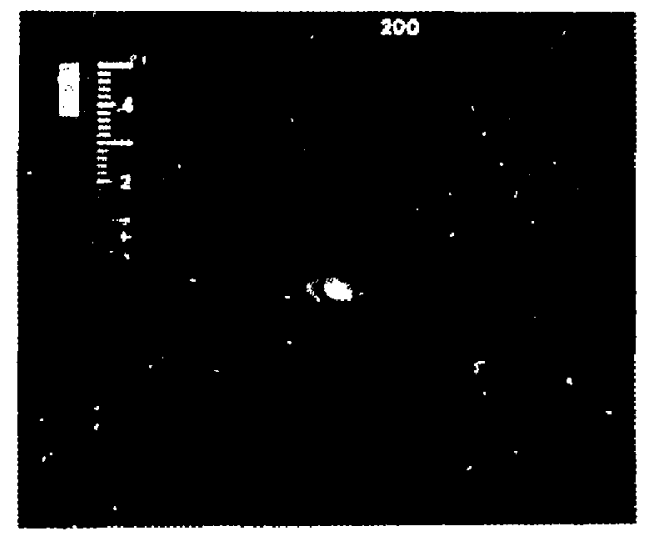

(a)

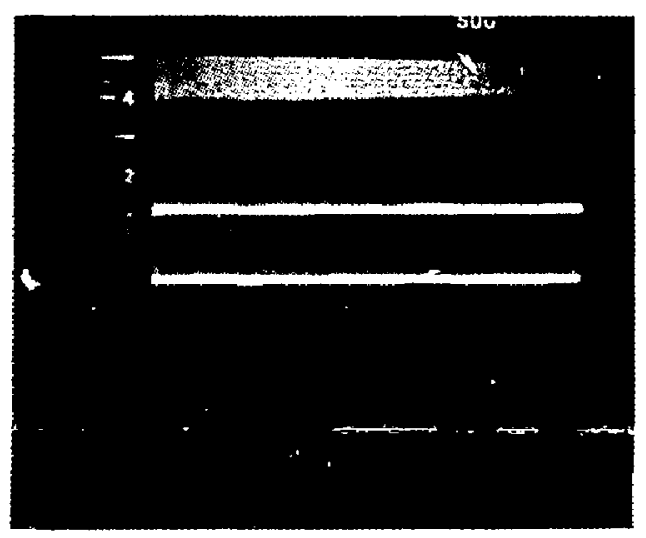

(c)

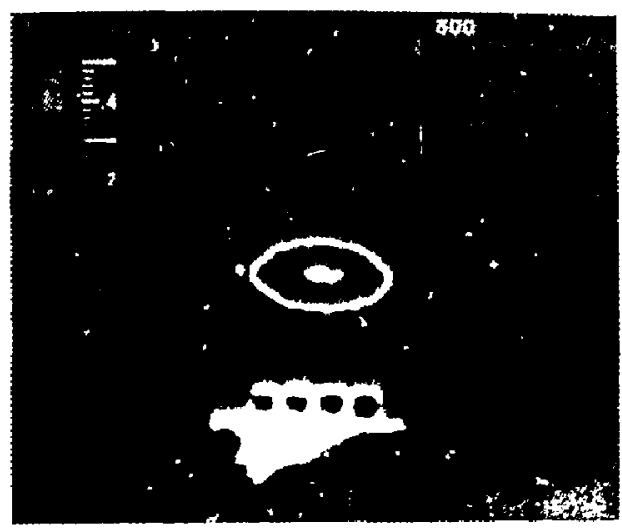

(b)

Figure 9. Samples of AGA infrared photographic data for $10-\pi m$ by $25-\mathrm{mm}$ apertures at two different power levels: (a) $74 \mathrm{~W}$ impinging window $2 \mathrm{~B}$ with white isotherms shut of $f$, (b) $85 \mathrm{~W}$ impinging window $2 \mathrm{~A}$ with isotherms turned on, (c) color bars corresponding to temperatures of (b). 


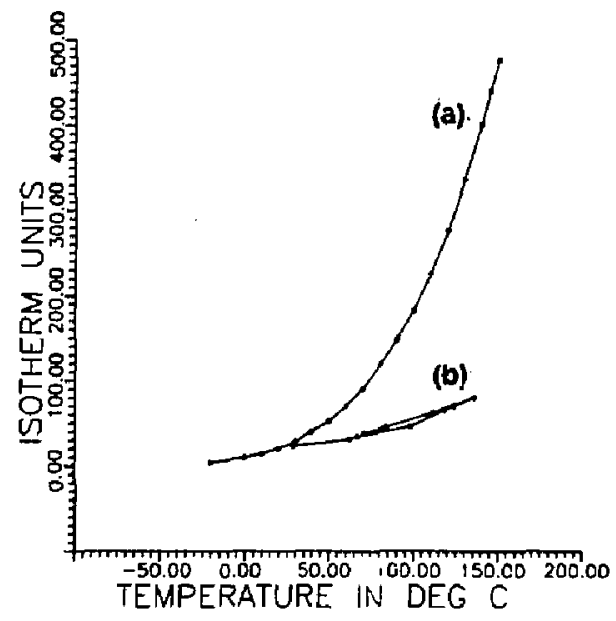

F1gure 10. Calibration curves for the AGA infrared camera: (a) top curve was obtained from operations manual for ideal blackbody, (b) bottom curve was measured with actual test cell wrapped with heater tape and well insulated. Average temperatures from thermocouplea TC-4 and TC-5 were recorded and plotted against AGA camera readings observed on the Be surface between the two thermocouples. 
Calibration curves shown in Fig. 10 were obtained from two sources. The AGA Camera manufacturer provided the top (blackbody) curve in its operations manual. The bottom curve was obtalned by wrapping the test cell with heater tape, insulating it, and reading the thermocouple temperatures on the Be along with the thermal isothermal units from the AGA Camera. The emissivity of the Be as measured in the AGA shortwave scanner's 3-to-6 $\mu$ m spectral range is a function of temperature. The ratios for rael te by=-ibody values (i.e., measured enissivities) are $0.55,0.30$, and 0.20 for temperatures of $50^{\circ} \mathrm{C}$, $100^{\circ} \mathrm{C}$, and $150^{\circ} \mathrm{C}$, respectively. These emissivity values seem reasonable, but need further study if used to do any extensive analysis.

System temperatures were monitored by thermocouples as schematically shown In Fig. 3. The back surface temperature of the Be foil was measured by iwo 0.03-mm (1-mil) thermocouples spot welded to the back surface. Thermocouple four (TC-4) was mounted 6.5 horizontally off-center. TC-5 was mounted on the geometric center of the Be window. TC-5 reads the hot spot back surface temperature of the centered laser bear as it impinges on the front of the Be window. TC-I, TC-2, and TC-3 read the temperature of the water entering the test cel1, while $\mathrm{TC}-6$ and $\mathrm{TC}-7$ read the exit water temperature. TC-8 reads room temperature. A Hanzon 4000 Series Digital Readout Data Logger with a Hewlett Packard Thinkjet Printer recorded thermocouple time-temperature data. Figure 11is shows a photo of the instrumentation and Fig. 11B a sample printer output of the peak temperature data taken for windows $1,2 \mathrm{~A}$, and 2B.

Energy of the laser was measured directly by dumping the beam into a calorimeter (Apollo Lasers InC., Model ALC and associated rec.dout, Model ACM-10i). Laser pulse rate in pulses per second (PPs) was determined with an oscilloscope connected to a detector directly on the laser rod.

Argon gas is supplied from a regulated building central supply system. The helium gas source is from a helium bottle with standard regulator. Both gas sources are regulated a second time with preclsion low-pressure regulators. These regulators are set at 15.1 psia $(0.4$ psig) pressure.

System gas valves were Nupro bellows valves qualified to $1 \times 10^{-6} \mathrm{std}$ $\mathrm{cm}^{3} \mathrm{He} / \mathrm{min}$ leak rate. The vacuum system consisted of a Welch rotary-vane vacuum punp with a liquid nitrogen foreline trap. This vacuum system normally provided a millitorr level vacuum. Two Granville-Philips Series 275 Digital Readout Convectron Vacuum Gages read in the vacuum-to-presgure range on each side of the test cell. 


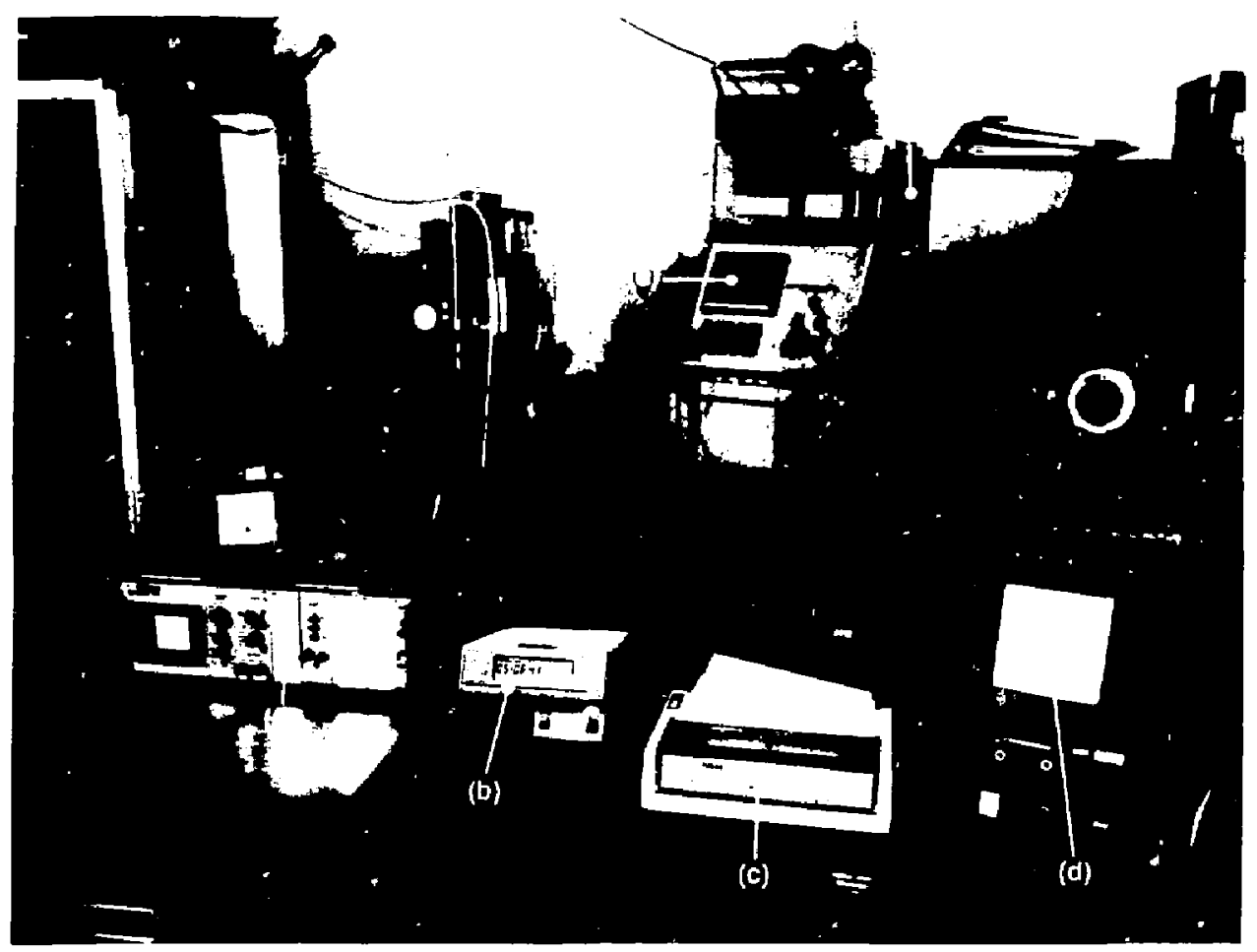

Figure 11A. Photograph of Be window test instrumentation showing: (a) AGA camera console, (b) Hanzon 4000 series digital temperature readout/data logger, (c) HP Thinkjet priater connected to Hanzon, (d) color monitor for AGA camera, (e) large console in center is X-Y-2 CNC control console, (f) large console to the right is the controller for the Raytheon laser with system parameters listed in Table 2. 


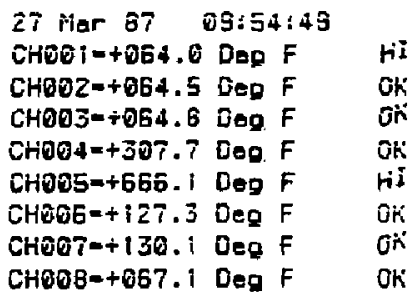

\section{(a) Window Number 1 Data}

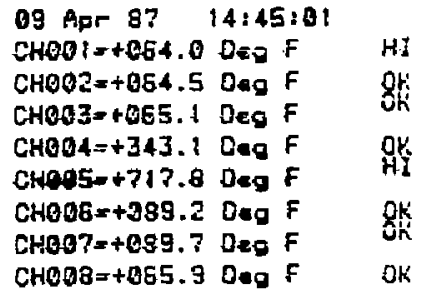

(b) Window Number 2A Data

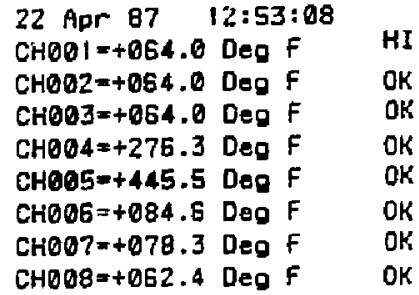

\section{(c) Window Number $2 B$ Data}

Figure 11B. Samples of data from Hanzon-4000/BP-Thinkjet for peak temperatures on windows $1,2 A$, and $2 B$. Thermocouples TC-1, TC-2, and TC-3 read water temperature entering the test cell; $\mathrm{TC}-4$ reads the back ourface temperature of Be window at $6.5-\mathrm{mm}$ horizontally off-center; TC -5 reads the back surface temperature of the center "hot spot" of the Be window; TC-6 and TC-7 read water temperature exiting the test cell; TC-8 reads room temperature. (Channel numbers correspond to the thermocouples.) 
A Masterflex varfable speed pump ( $97 \mathrm{ml} / \mathrm{min}$ maximum flow rate) from cole Parmer controlled the flow rate of cooling water to the test cell. Most tests were run with $10^{\circ} \mathrm{C}$ to $20^{\circ} \mathrm{C}$ temperature rise between supply and return of the Be window cooling water.

A Ntkon long-focal-length microscope, typically known as a "surgeons microscope," was used to look at the Be window within the test cell. With this unit, the silghtest change of surface characteristics was readily observed.

\section{DESCRIPTION OF THE EXPERIMENT}

The experimental parameters are: beam size and shape, beam power, laser pulse shape and rate, coolant flow rate to the test cell, test cell chamber pressures, and window illumination time intervals. Beam shape is rectangular, measuring approximately 2-mm wide by 14-mm long in size. It is oriented on the window with its long axis corresponding to the horizontal axis of the window aperture. Laser pulse shape and rate are set close to meximum laser power conditions and as close to steady-state as is reasonably possible. The laser runs well for long periods at $100 \mathrm{pps}$, but is much less stable at the higher pulse rates. Therefore the 100 pps rate became the standara for all the test runs. This laser power condition approximates synchrotron thermal heat loads for Be windows at SSRL, which sees an in situ constant heat flux due to the orbiting electrons. Coolant flow rate is measured with a stop watch and a millilitre flask.

The energy density profile of the beam is measured by covering the calorimeter aperture with a slitted mask 0.131 m by $12.931 \mathrm{~mm}$, allowing only a small fraction of the beam to pass on to the detector. Initially, the long axis of the slit is positioned on the long axis of the beam shape. Energy measurements are made for half-second illumination periods across the beam profile in the vertical direction in $0.1-\mathrm{mm}$ increments. Next, the mask is turned $90^{\circ}$, and the measurement process is repeated in $0.5-\mathrm{mm}$ increments along the horizontal axis. In either case the energy measured represents the average energy over the whole area of the slit for its relative position in the beam profile.

Figures $12 \mathrm{~A}$ through $12 \mathrm{~F}$ show the slit-average beam energy plotted as a function of slit position relative to the laser beam. The integrated area under the plotted curves divided by the slit width $(0.131 \mathrm{~mm})$ is equal to the 


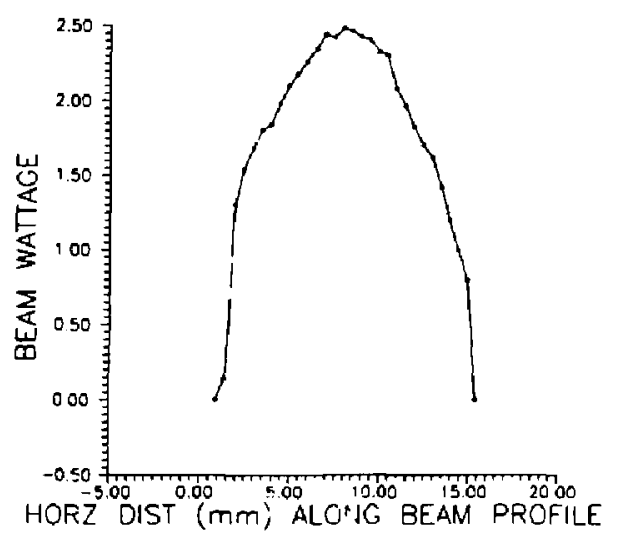

(a)

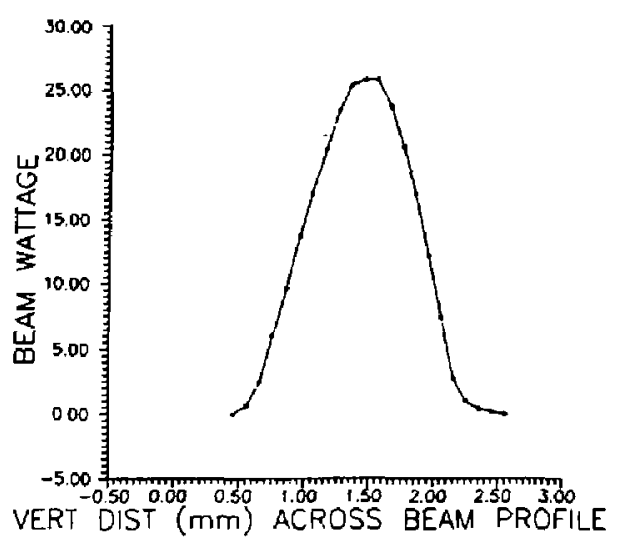

(b)

Figure 12. Plote of data for laser beam energy density profiles obtained by scanning the narrow part of a 81 it-mask ( $0.131 \mathrm{~mm}$ by $12,9 \mathrm{~mm}$ ) horizontally and verticaliy at the focal plane of the front ideal surface of the Be window: (a) $200 \mathrm{~W}$, horizontal; (b) $200 \mathrm{~W}$, vertical; (c) $100 \mathrm{~W}$, horizontal; (d) $100 \mathrm{~W}$, vertical; (e) $87 \mathrm{~W}$, horizontal; (E) $87 \mathrm{~W}$, vertical. 


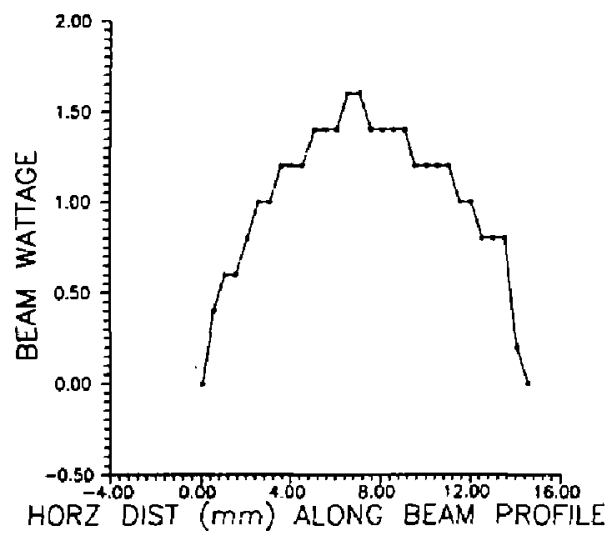

(c)

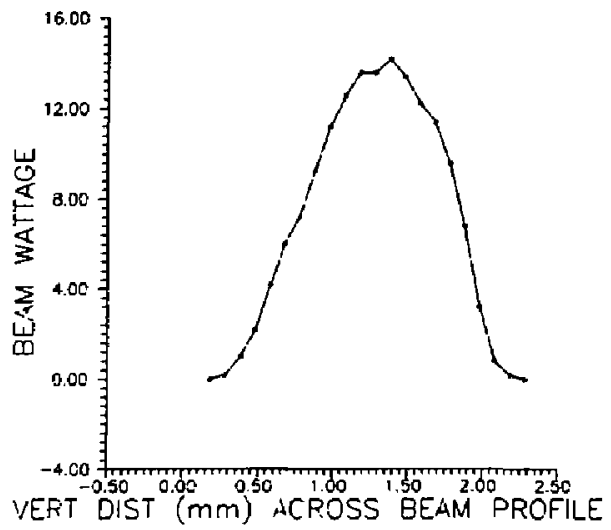

(d)

Figure 12 (Continued). 


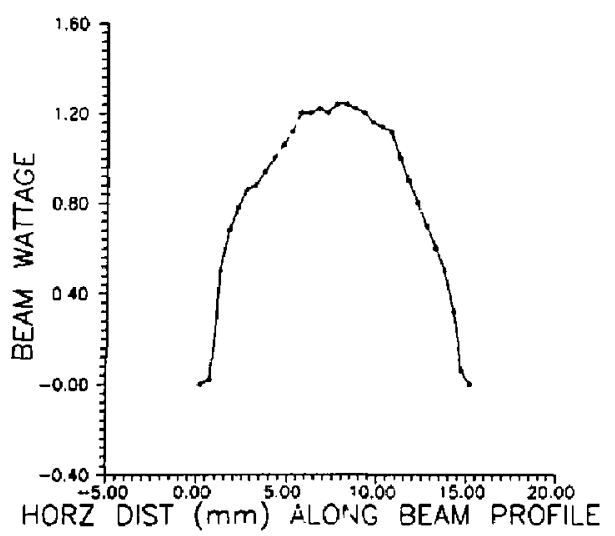

(e)

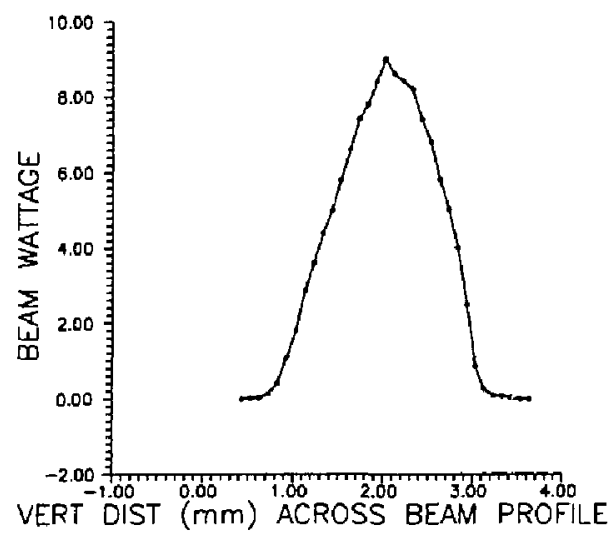

(f)

Figure 12 (Continued). 
total beam energy. Similiar measured distributions, both horizontally and vertically, are seen by Be windows when subjected to synchrotron radiation thermal loads. The primary difference is that the synchrotron therral load (1.e., with carbon filters used upstream from the Be window) is dfpesited almost uniformly through the thickness of the beryllium (volumetrically), whereas the laser thermally impinges the Be surface only. Without carbon filters, surface thermal loads are expected, in which case our experiment comes closer to in situ simulation. Once absorbed within the Be, most of the heat is carried away by conduction through the Be to the water-cooled copper aperture in virtually the same manner for both cases. An absorption coefficient for the Be surface at the NdiYag laser wavelength of 1.06 m was not successfully measured with this experimental setup. The energy scattered within the cell could not be separated from that absorbed in the beryllium and transferreu to the copper as measured by water temperature rise data coupled with the constant water flow rate.

\section{EXPERIMENTAL PROCEDURE}

Test cell preparation begins with the front and rear chambers being evacuated after flushing twice with argon. The rear chamber is then filled to 0.4 psig ( 15.1 psia) of helium gas. The front chamber remains evacuated at an average gage test pressure of approximately 25 millitorr argon [converted pressure of 42 millitorr for air $\left(N_{2}\right)$ equivalent]. Cooling water flow rate to the test cell from the Masterflex pump is set.

To confirm the beam shape, a burn on the target block is conducted befor: aligning the beam onto the Be window. The data logger is set to 30-s scan intervals. The AGA Thermovision system is turned on and the camera itself is filled with liquid nitrogen along with the vacuum foreline trap.

With all preparations completed, the laser shutter is opened and the window is heated with the focused laser beam. A particular beam energy is maintained for initially a 30-min interval and repeated unless damage has been observed and additional damage is occurring slowly. If this happens, a one-hour run time interval is chosen. Visual inspection for surface damage of the Be window is made after each exposure. 
Table 3 contains an overview of all the pertinent experımental parameters along with some calculated key parameters. Figures $13 \mathrm{~A}-13 \mathrm{E}$ and $14 \mathrm{~A}-14 \mathrm{~J}$ are photomicrographs and scanning electron micrographs (SEM) of the associated metallographic results. Table 4 contains all the detailed data of the runs for Be windows 1, 2A, and $2 B$.

\section{MECHANICAL LOADING OF THE Be WINDOWS}

Al1 three windows tested are made with $0.254-$ mn $(10-m i 1)$ thick Be foil. Both aperture types tested had a convex side that faced the vacuum chamber; this was also the side lmpinged upon by the laser. This initial curvature is apparently the result of the differential contraction during the cooling portion of the vacuum brazing frocess of the two different materials ( $B e$ and ru) being brazed together, plus any initial Be curvature. Beryllium window surface curvature measurements before and after laser testing revealed vertical curvature growth. Window $2 B$ was the only one of the three windows measured before and after testing with a measured vertical curvature growth of 78\%. Beryllium windows $2 A$ and $2 B$ had different $f$ inal measured curvatures of $1.168 \mathrm{~mm}$ and $0.818 \mathrm{~mm}$, respectively. This was evidently not a tightly controlled parameter during the fabrication process.

Surface finish before testing varied on all windows, with surface scratches apparent at all levels of magnification. These surface defects provide potential stress concentration locations for surface cracks to develop.

THERMAL DIFFERENTIAL LOADING OF TEE Be WINDOWS

Large temperature gradients from the beam-impinged region on the window to the copper heat sink causes differential thermal expansion between the Be and the copper. This results in additional window distortion. For example, from the data documented in Table 3, the cencer thermocouple of window $2 A$ read $381^{\circ} \mathrm{C}$ with $85 \mathrm{~W}$ impinging the Be. For the same power load the thermocouple of fet $6.5 \mathrm{~mm}$ on the long axis registered a temperature of $173^{\circ} \mathrm{C}$. The exit temperature of the cooling water was $32^{\circ} \mathrm{C}$. The calculated average thermal Bradient between the two thermocouples is $32^{\circ} \mathrm{c} / \mathrm{mm}$. Using the waver exit temperature, a conservative estimate for the Be-copper interface is $32^{\circ} \mathrm{C}$. The 
Table 3. Summary of test results of the Be window thermal damage study.

\begin{tabular}{|c|c|c|c|c|c|c|c|c|c|c|c|c|c|}
\hline $\begin{array}{l}\text { Hindow } \\
\text { No. }\end{array}$ & $\begin{array}{l}\text { Power im- } \\
\text { pinglng } \\
\text { window } \\
(W)\end{array}$ & $\begin{array}{l}\text { Elapsed } \\
\text { time at } \\
\max \text { Dwr } \\
(\mathrm{hr})\end{array}$ & $\begin{array}{l}\text { Hax temp } \\
\text { of window } \\
\text { center } \\
\text { TC-5 } \\
\left({ }^{\circ} \mathrm{C}\right)\end{array}$ & $\begin{array}{l}\text { Hax temp } \\
\text { of windaw } \\
6 \mathrm{~mm} \text { off - } \\
\text { set TC-4 } \\
\left({ }^{\circ} \mathrm{C}\right)\end{array}$ & $\begin{array}{l}\text { Cooling } \\
\text { water } \\
\text { temp } \\
\text { rise } \\
\left({ }^{\circ} \mathrm{C}\right)\end{array}$ & $\begin{array}{l}\text { cooling } \\
\text { water } \\
\text { flow } \\
\text { rate } \\
(\mathrm{ml} / \mathrm{s})\end{array}$ & $\begin{array}{l}\text { Heat } \\
\text { flux to } \\
\text { cooling } \\
\text { water } \\
\text { (W) }\end{array}$ & $\begin{array}{l}\text { Heat } \\
\text { lost } \\
\text { to the } \\
\text { room } \\
\text { (H) }\end{array}$ & $\begin{array}{l}\text { Heat } \\
\text { lost } \\
\text { to the } \\
\text { room } \\
(x)\end{array}$ & $\begin{array}{l}\text { Horiz } \\
\text { tenp } \\
\text { grad } \\
\text { TC-4 to } \\
\text { TC-5 } \\
\left({ }^{\circ} \mathrm{C} / \mathrm{mm}\right)\end{array}$ & $\begin{array}{l}\text { Vert } \\
\text { temp } \\
\text { grad } \\
\text { TC-5 to } \\
T C-6 \\
\left({ }^{\circ} \mathrm{C} / \mathrm{mm}\right)\end{array}$ & $\begin{array}{l}\text { Vert } \\
\text { to hor:- } \\
\text { temp } \\
\text { grad } \\
\text { ratio }\end{array}$ & $\begin{array}{l}\text { Damage } \\
\text { noted }\end{array}$ \\
\hline 1 & 170 & 0.5 & 352 & 153 & 18 & 1.57 & 118 & 52 & 37 & 31 & 120 & 3.9 & \multirow{3}{*}{$\begin{array}{l}\text { Surface } \\
\text { cracks } \\
\text { Tnrough } \\
\text { cracks } \\
\text { Localized } \\
\text { surface } \\
\text { damage }\end{array}$} \\
\hline $2 A$ & 85 & 3.0 & 381 & 173 & 14 & 1.20 & 70 & 15 & 18 & 31 & 70 & 2.2 & \\
\hline $2 B$ & 74 & 6.0 & 230 & 136 & 10 & 0.83 & 35 & $39^{b}$ & $53^{D}$ & 15 & 40 & 2.7 & \\
\hline
\end{tabular}

a The sapnire window absorbs approximately $15 \%$ of the laser power as measured by dumping a focused beam into the calorimeter with and without the sappire window in the beam dath.

DThe insulation that was used to wrap the test cell had been removed to speed up the time to reach steady-state for each li2-hour run cycle for the last nalf of the test serles on the third window. 

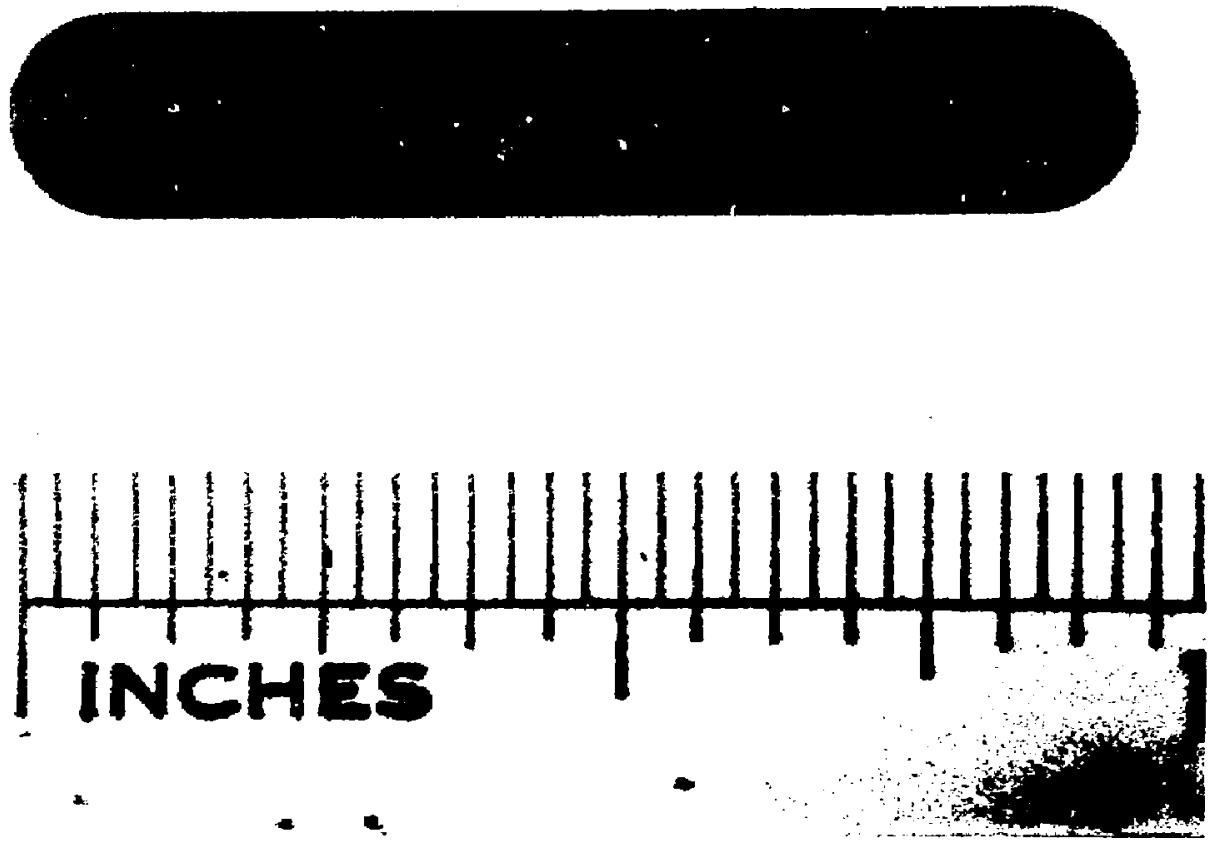

Figure 13A. Enlarged 6X macrograph of front surface of Be window 1 after 64 min of laser impingement or 384,000 pulses. The central portion shows visual signs of laser-induced surface damage. (Note: this and subsequent figures give enlargements taking $1.58 \mathrm{X}$ enlargenent for this report into account.) 


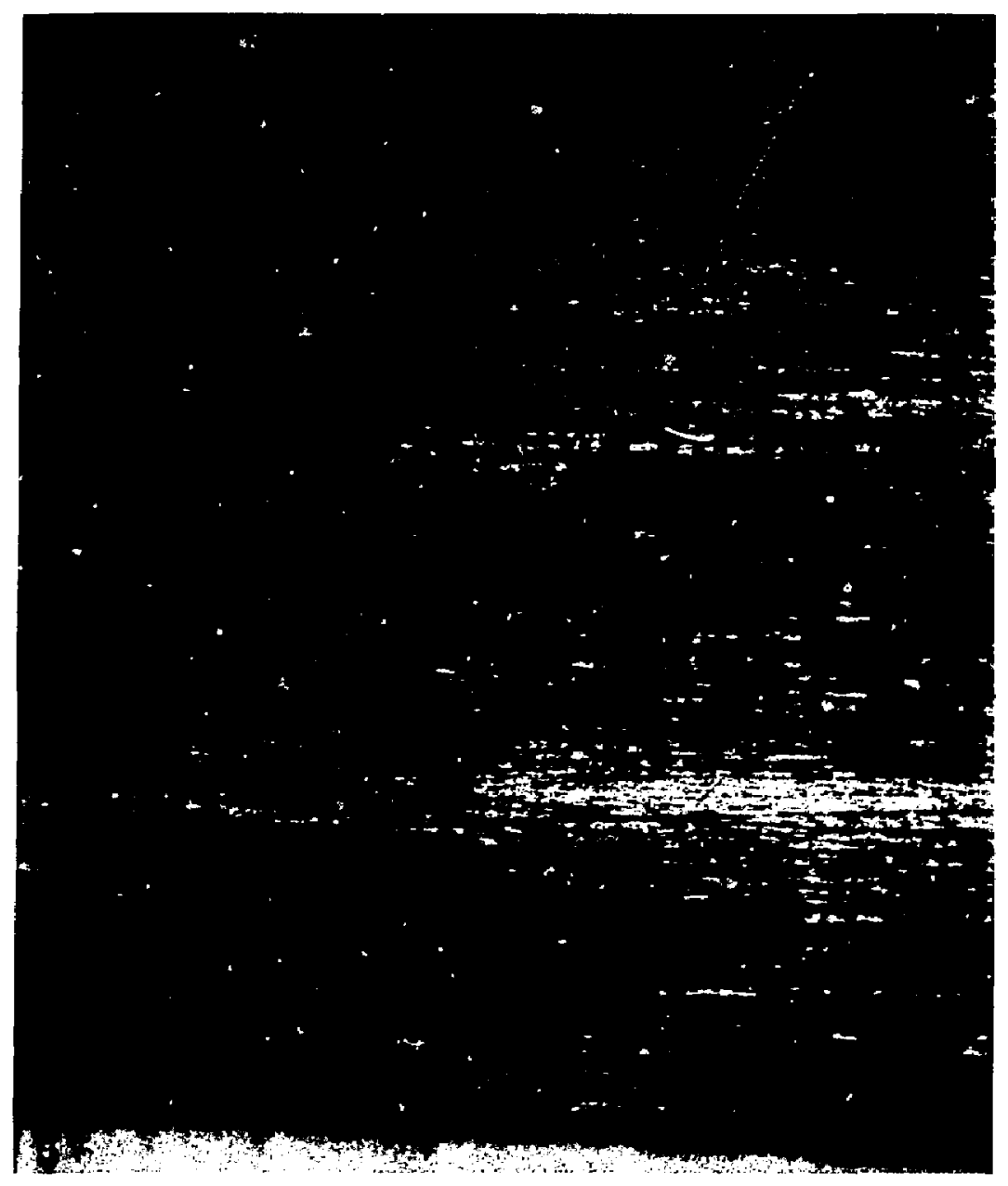

Figure 13B. Enlarged 60X photomicrograph of surface damage region of Be window 1 after 384,000 laser pulses. Surface shows signs of micracracking. 


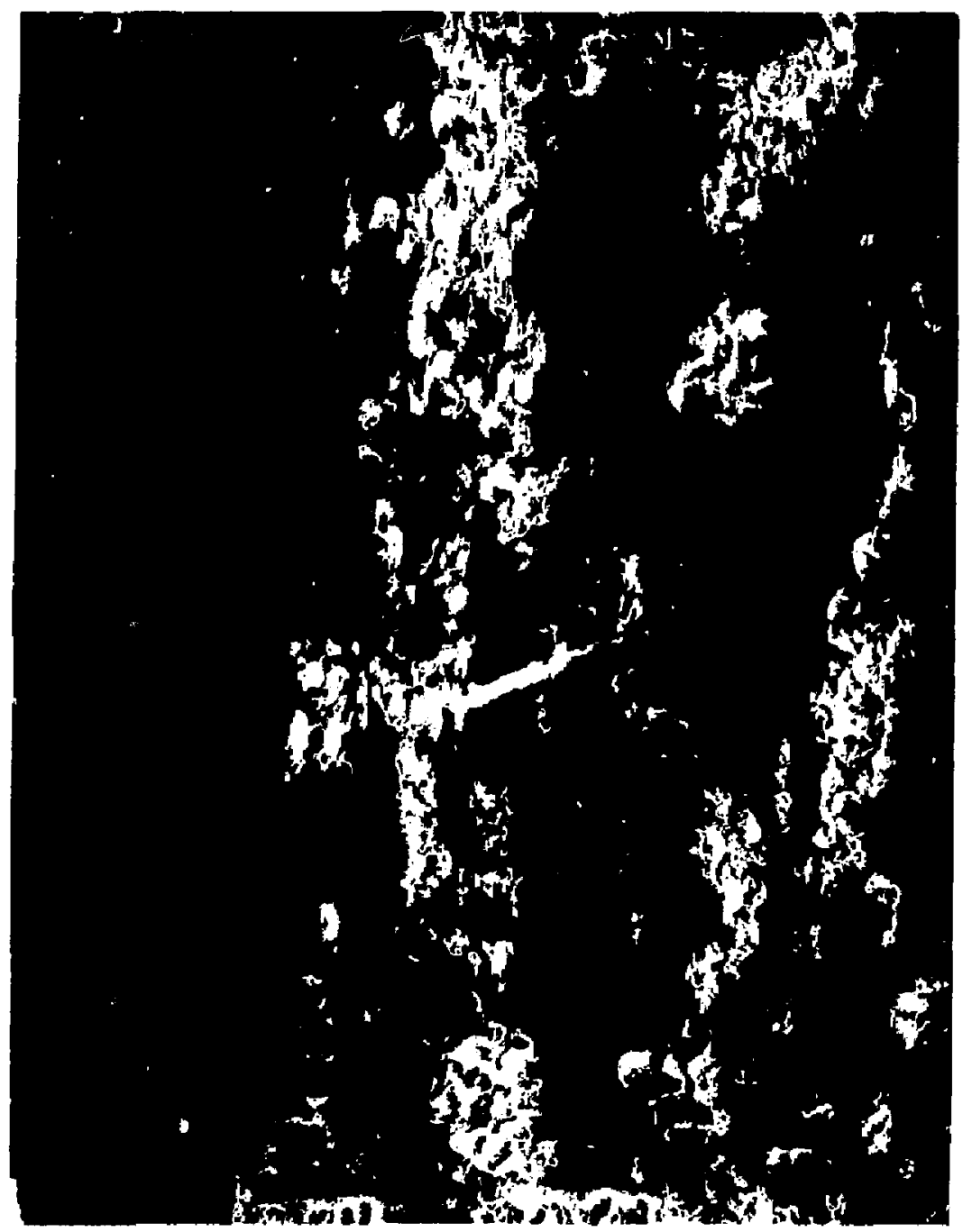

Figure 13C. Enlarged 600X SEM of surface damage region of Be window 1 after 384,000 laser pulses. At this magnification, areas of possible surface melting are visible in regions surrounding high intensities of microcracking. 


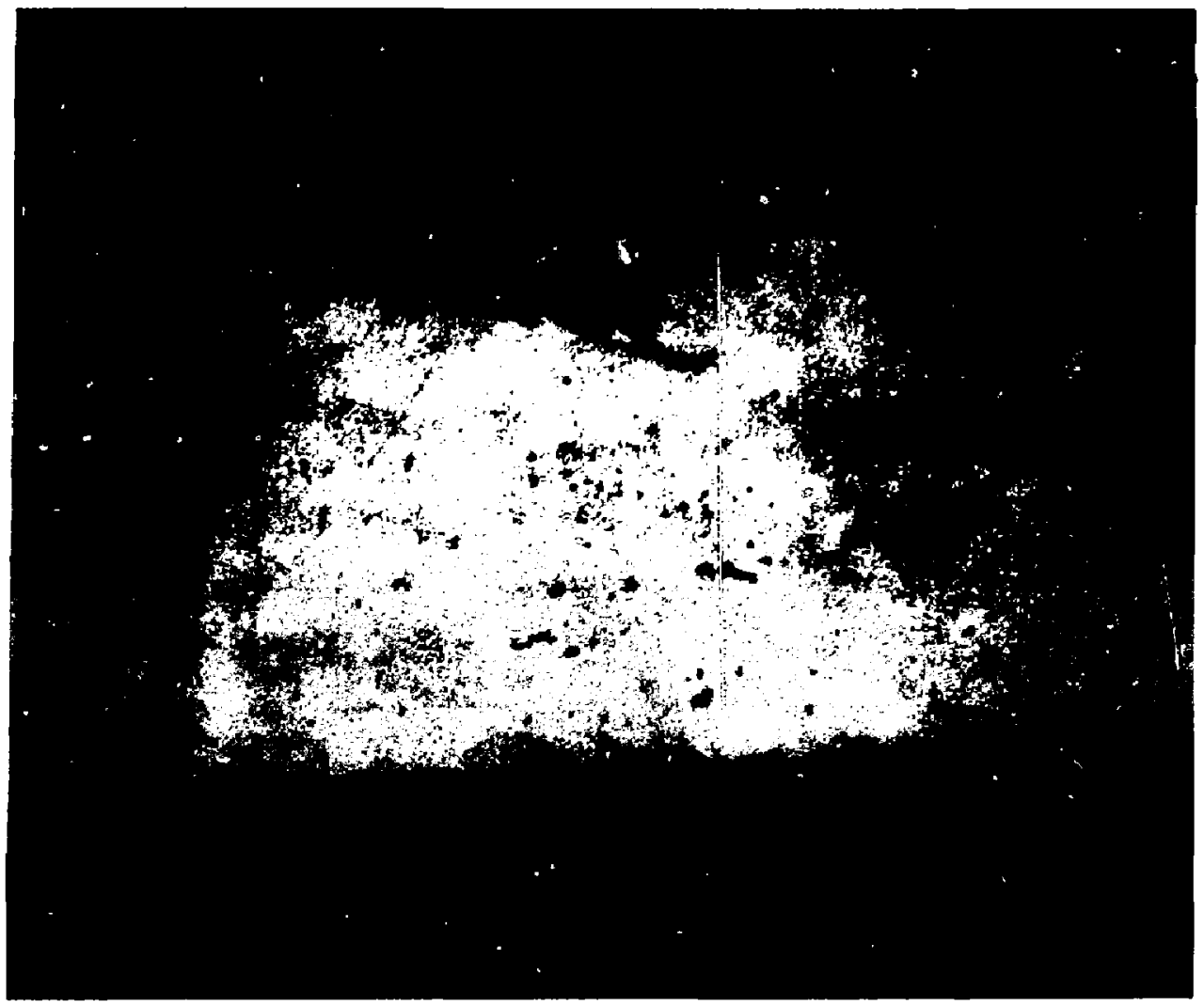

Figure 13D. Enlarged $300 x$ photomicrograph of a transverse section showing surface damage of Be window 1 after 384,000 laser pulses. Material void imperfections associated with cracking are evident. 


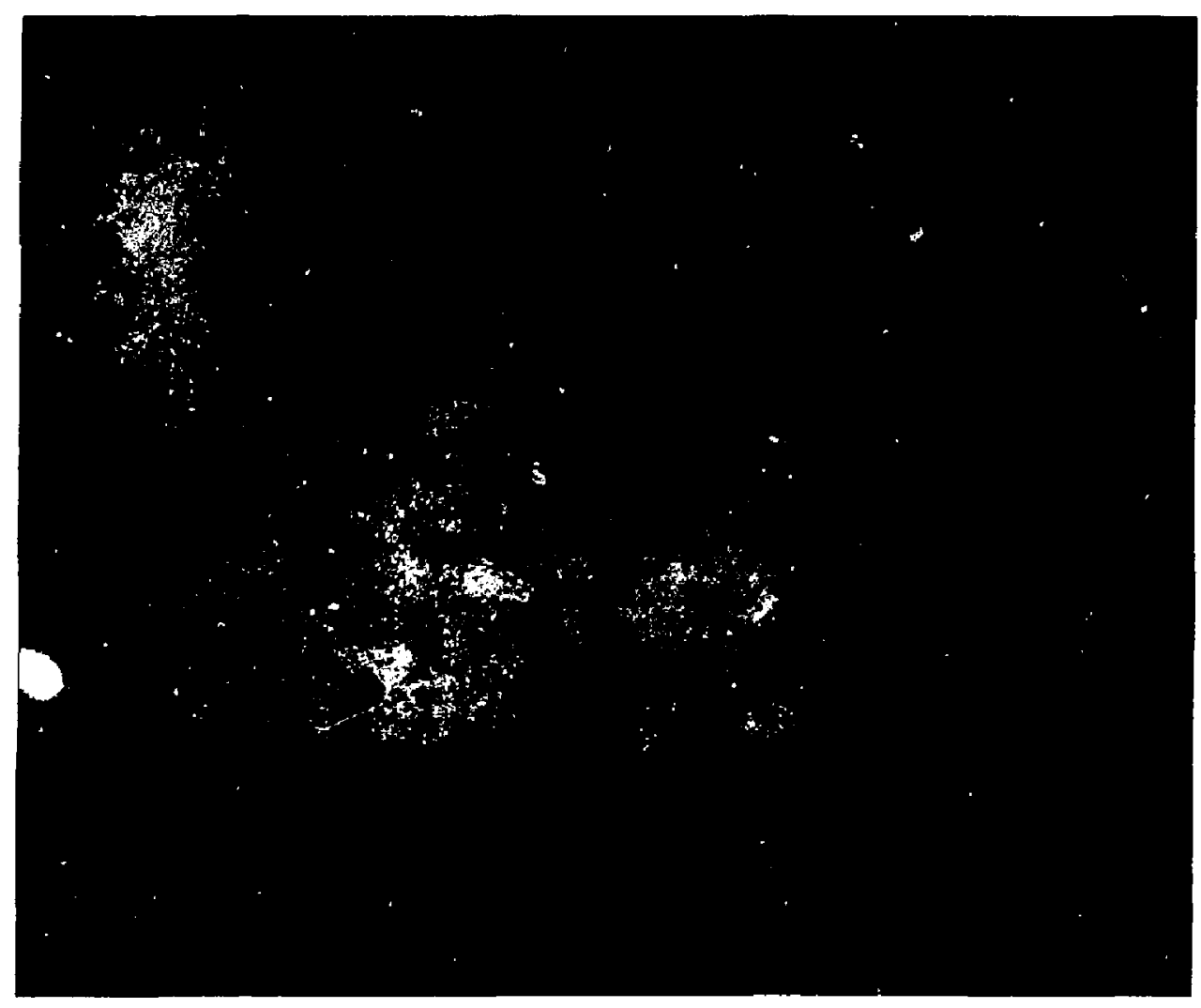

Figure 13E. Enlarged $300 \mathrm{x}$ photomicrograph of a transverse section showing surface damage and associated surface cracks for Be window 1 after 384,000 laser pulses. 


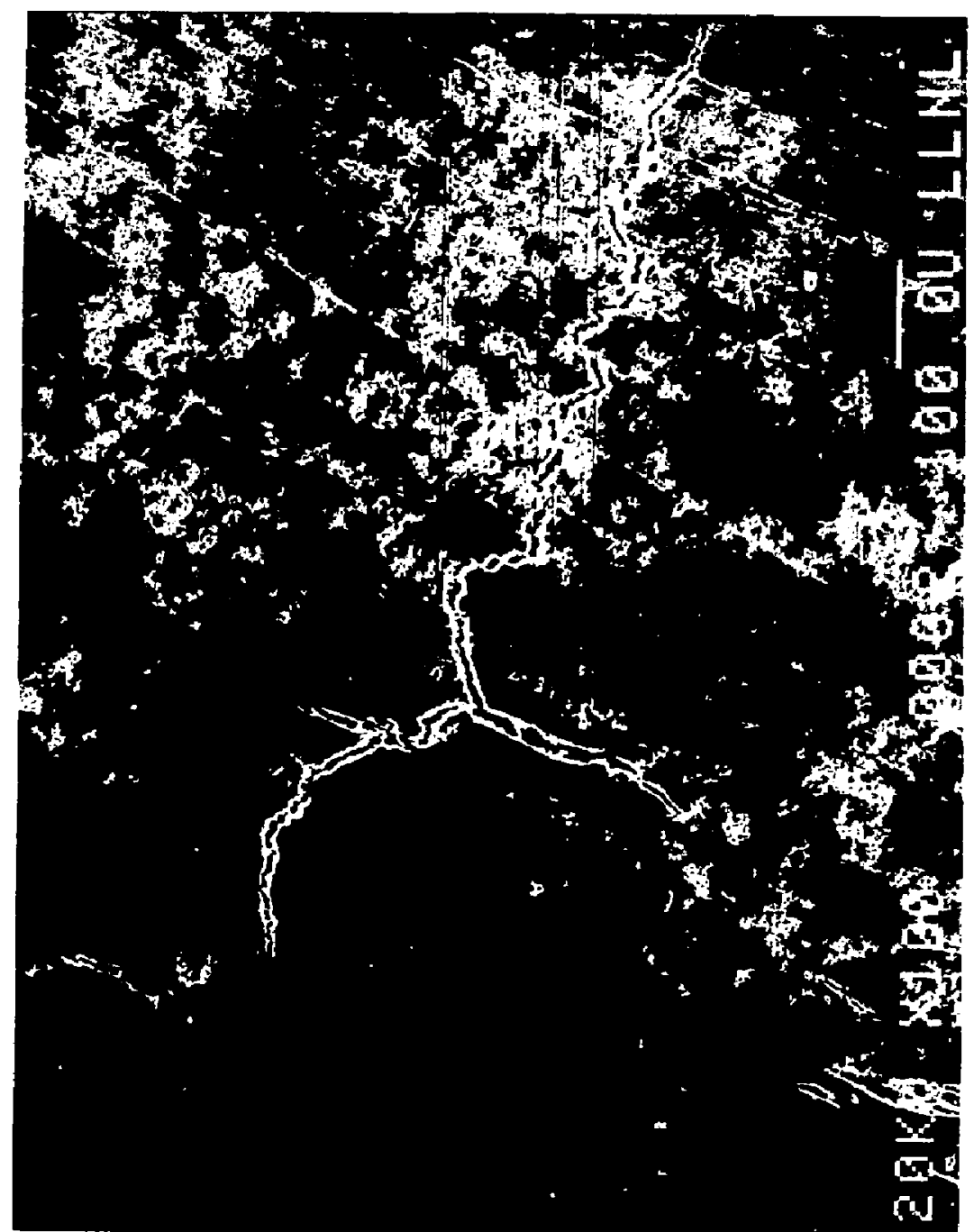

Figure 14A. Enlarged 150X SEM of front surface of Be window $2 \mathrm{~A}$ af ter $181 \mathrm{~min}$ of laser impingement for a cotal of $1,086,000$ pulses. Vertical crack with a smaller horizontal crack intersection shown with view rotated $30 \mathrm{deg}$. from horizontal. 


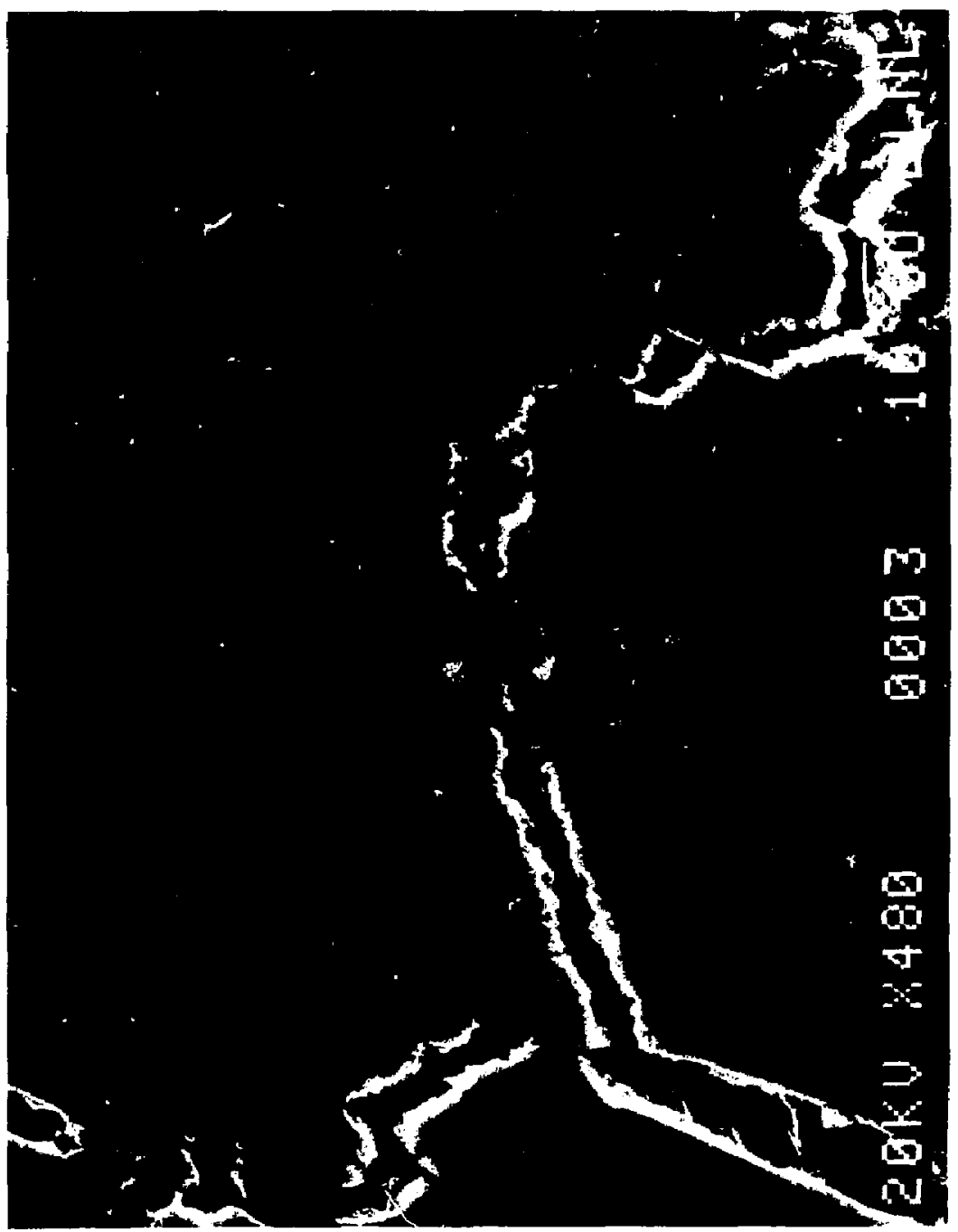

Figure 14B. Enlarged $750 X$ SEM of front surface of Be window $2 \mathrm{~A}$ after $181 \mathrm{~min}$ of laser impingement for a total of 1,086,000 pulses. Vertical crack with a smaller horizontal crack intersection shown with view rotated $30 \mathrm{deg}$ from horizontal. 


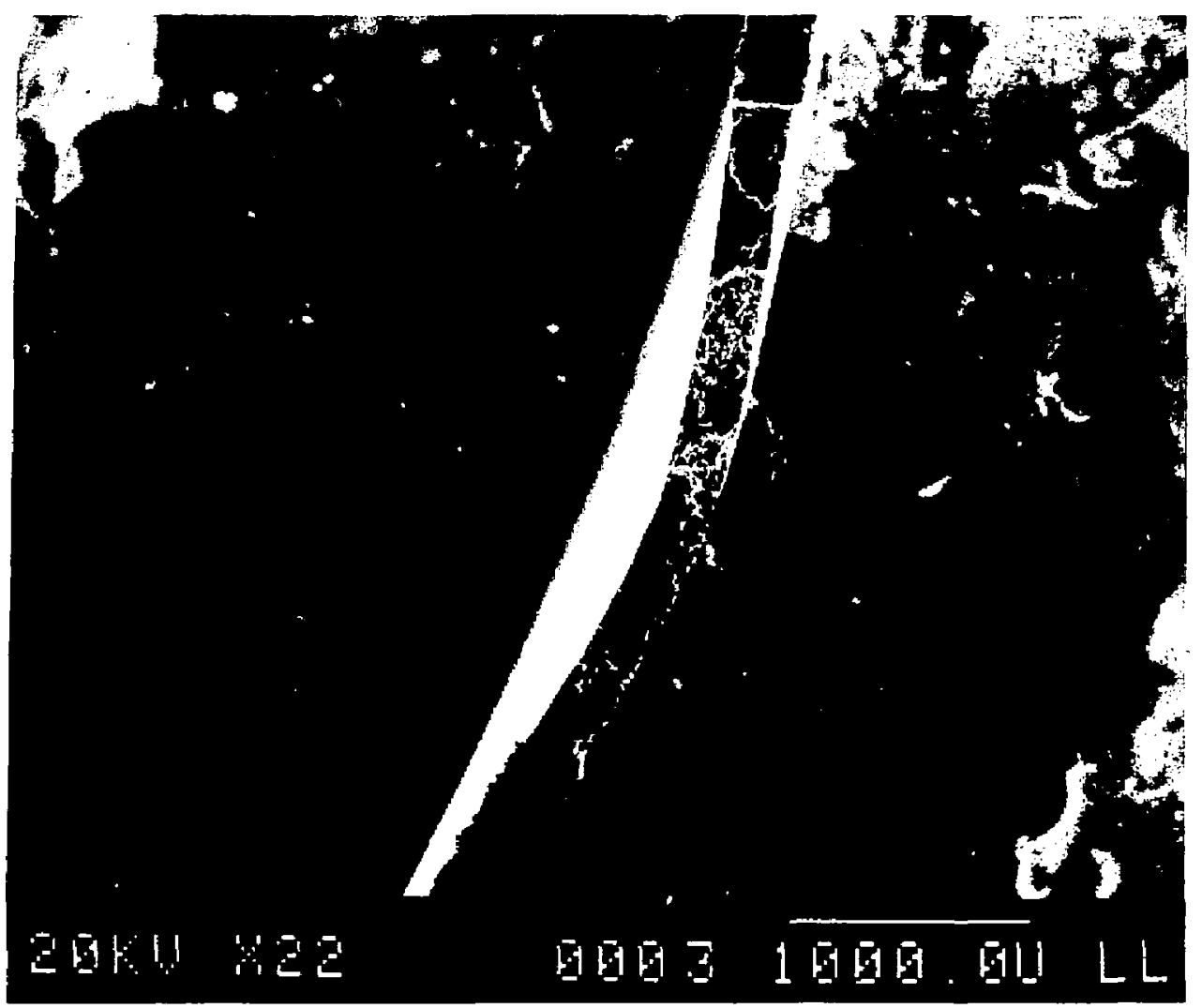

Figure 14C. Enlarged $35 \mathrm{X}$ SEM of vertical crack surface of Be window $2 \mathrm{~A}$ af ter $1,086,000$ laser pulses. Crack is split open exposing the vertical crack surface show with very different surface texture within (lower) and outside (upper) the area impinged by the laser beam. The crack surface within the focused laser beam shows signs of surface melting. 


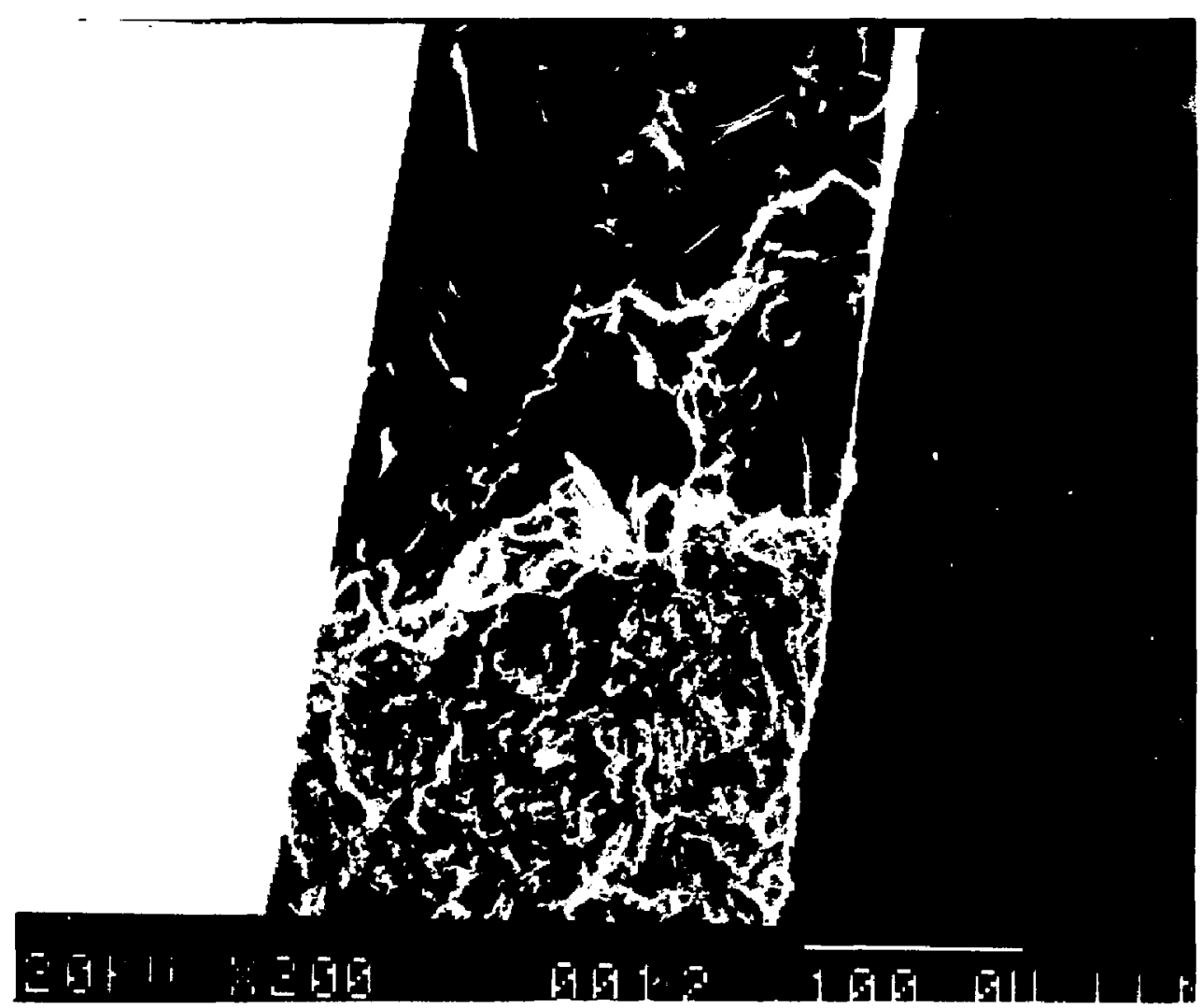

Figure 14D. Enlarged 300X SEM of vertical crack surface of Be window $2 \mathrm{~A}$ af ter $1,086,000$ laser pulses. Crack is split open exposing the vertical crack surface shown with very different surface texture within (lower) and outside (upper) the area impinged by the laser beam. The crack surface within the focused laser beam shows signs of surface melting. 


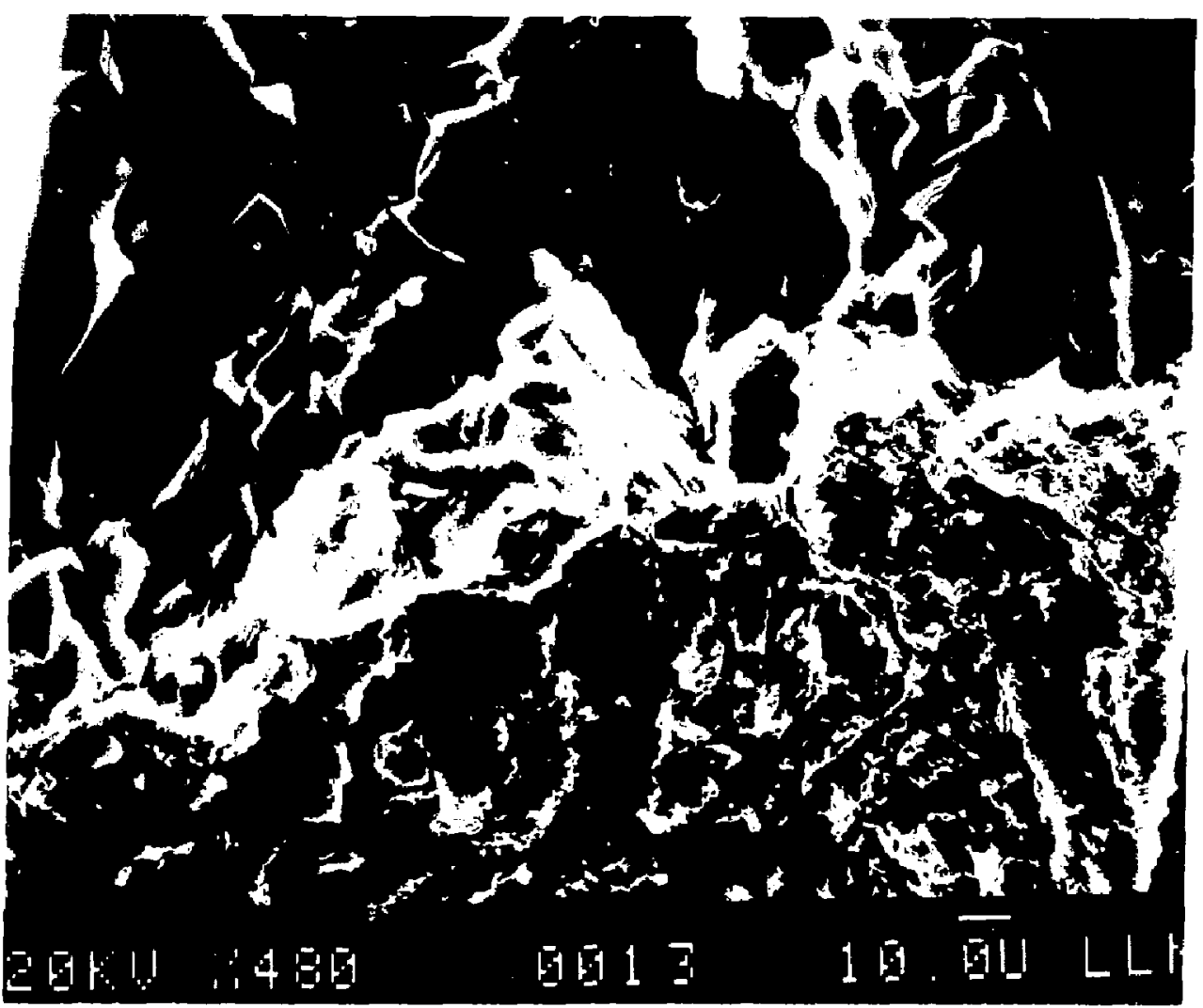

Figure 14E. Enlarged $750 X$ SEM of vertical crack surface of Be window $2 A$ after $1,086,000$ laser pulses. Crack is split open exposing the vertical crack surface shown with very different surface texture within (1ower) and outside (upper) the area impinged by the laser beam. The crack surface within the focused laser beam shows signs of surface melting. In the upper area, careful observation shows crack surface microcracking. 


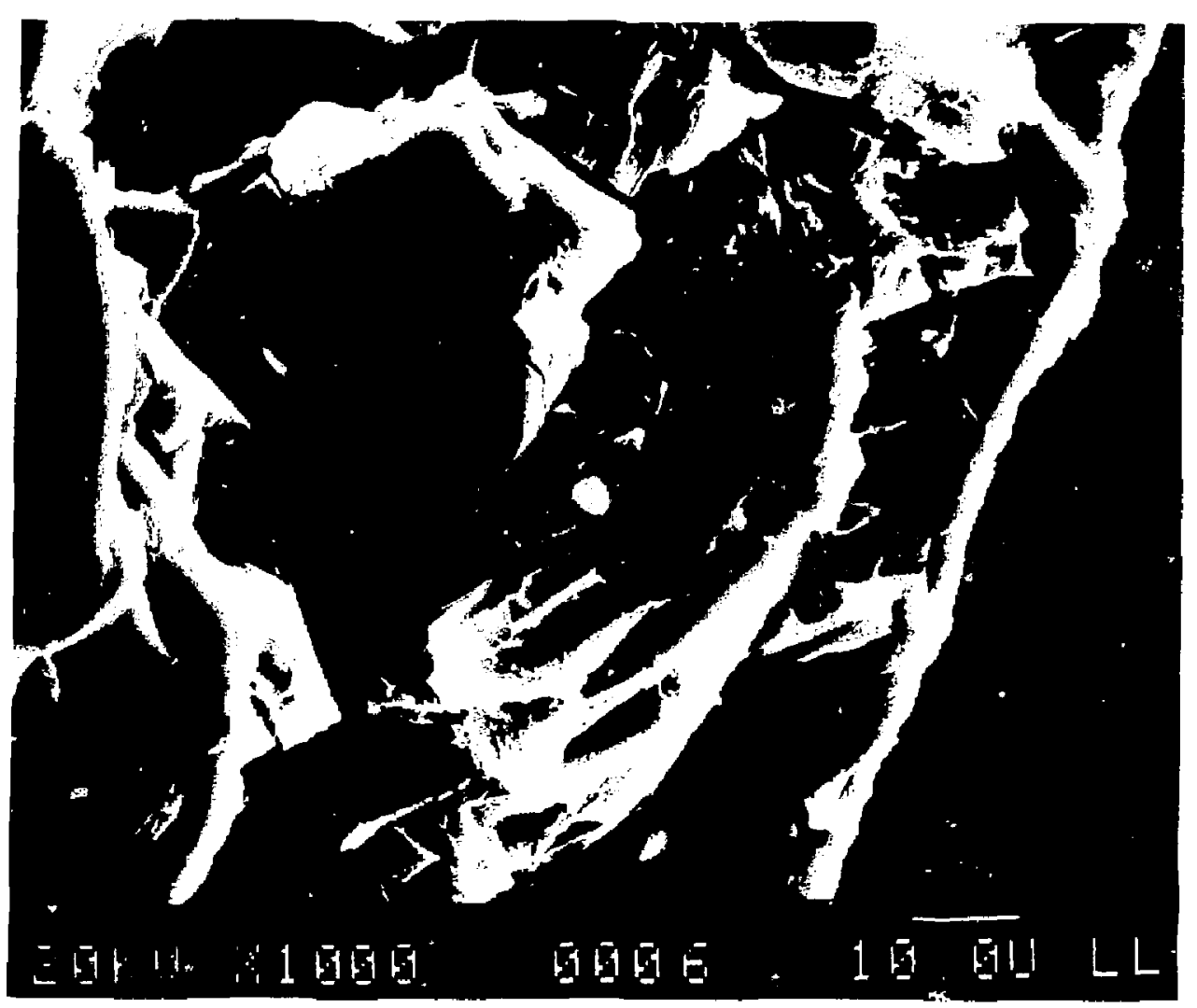

Figure 14F. Enlarged 1570X SEM of vertical crack surface of Be windown 2A after $1,086,000$ laser pulses. Crack is split open exposing the vertical crack surface shown with crack surface microcracking easily observed outside the focused laser beam. 


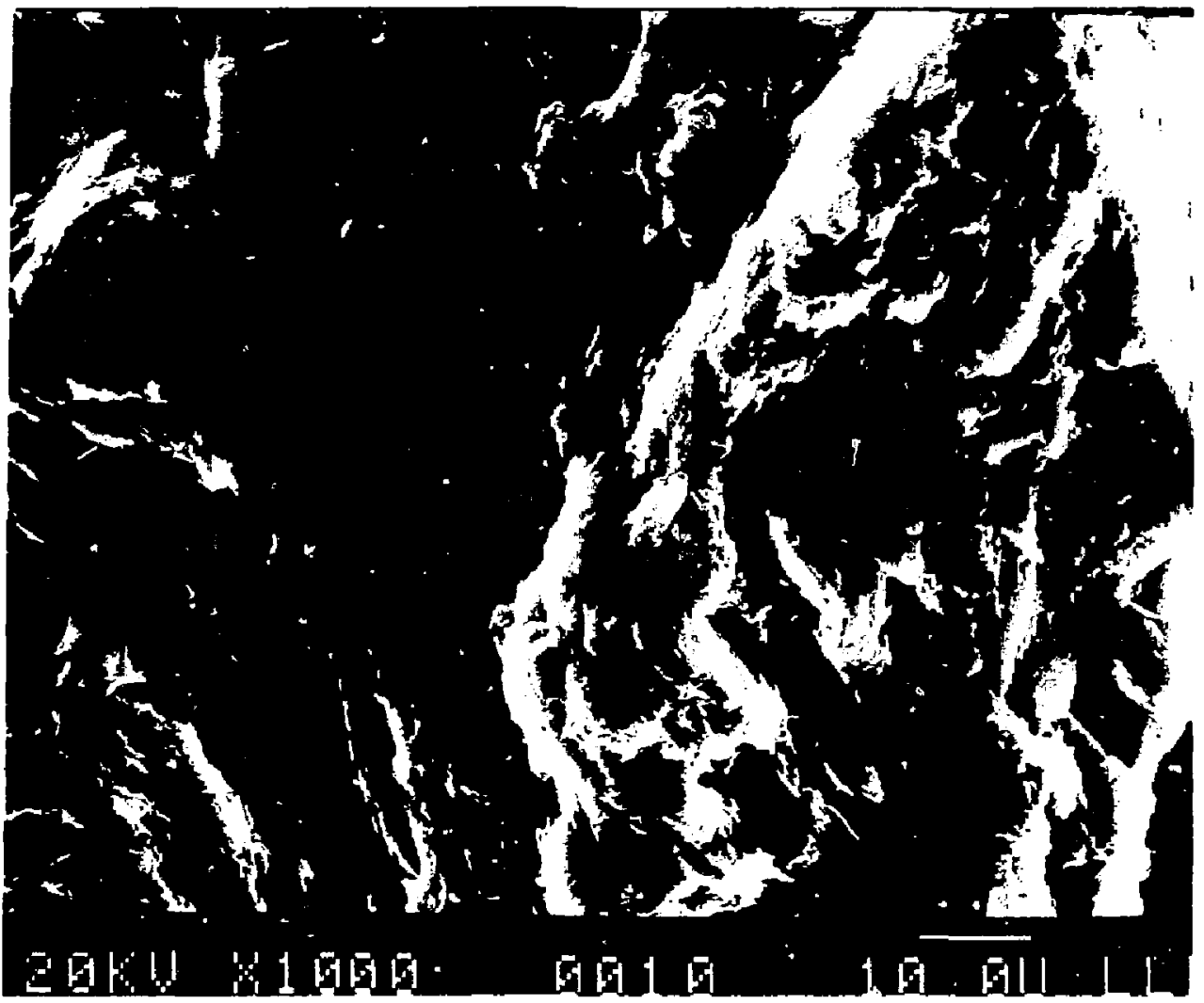

Figure 14r. Enlarged $1570 x$ SEM of vertical crack surface of Be window $2 \mathrm{~A}$ af ter 1,086,000 laser pulses. Crack is split open exposing the vertical crack surface shown under the area impinged by the laser beam. The crack surface shows signs of surface melting. 


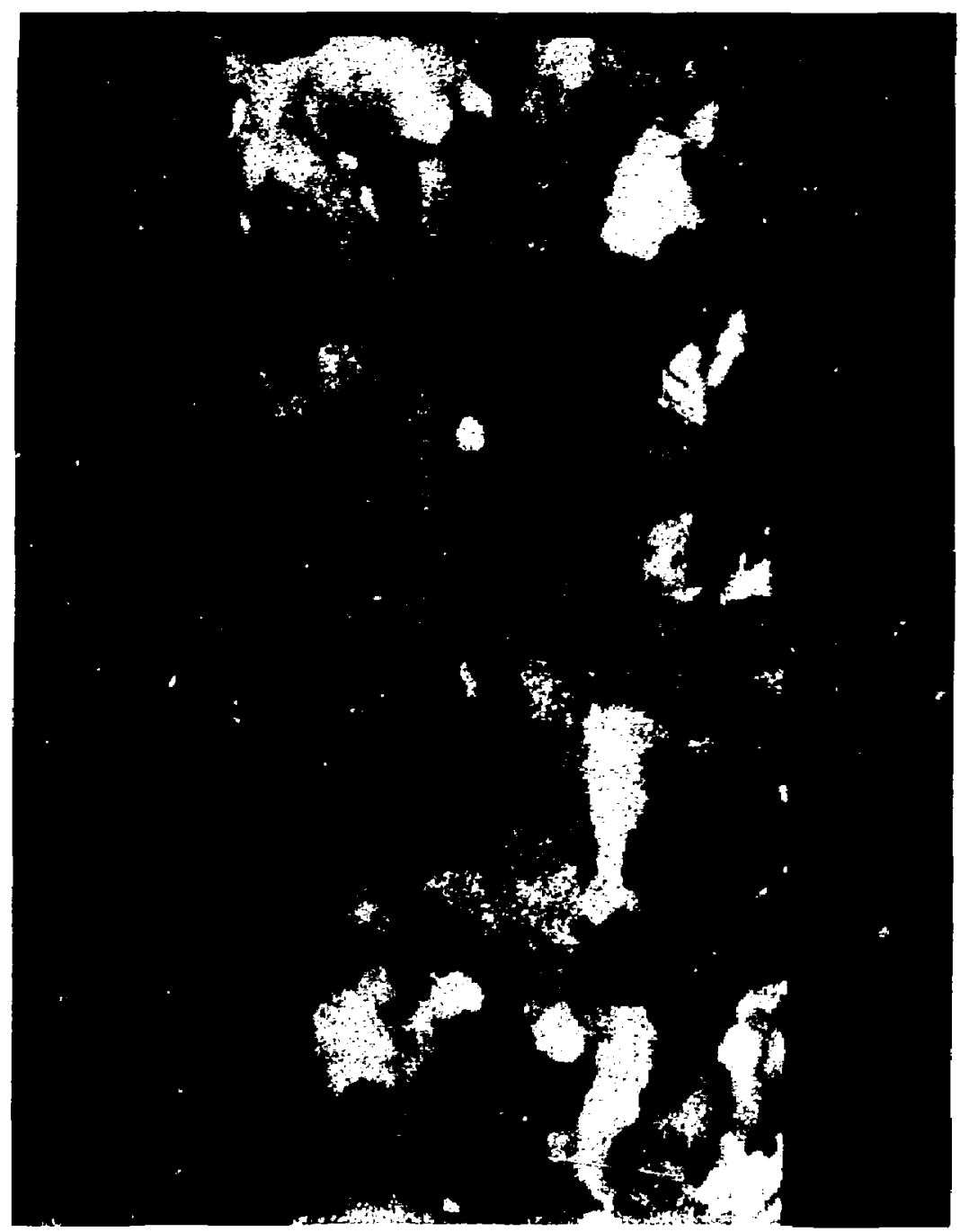

Figure 14H. Enlarged $300 \mathrm{X}$ transverse polished photomicrograph section of Be window $2 \mathrm{~A}$ after $1,086,000$ laser pulses showing horizontal crack at the apex. 


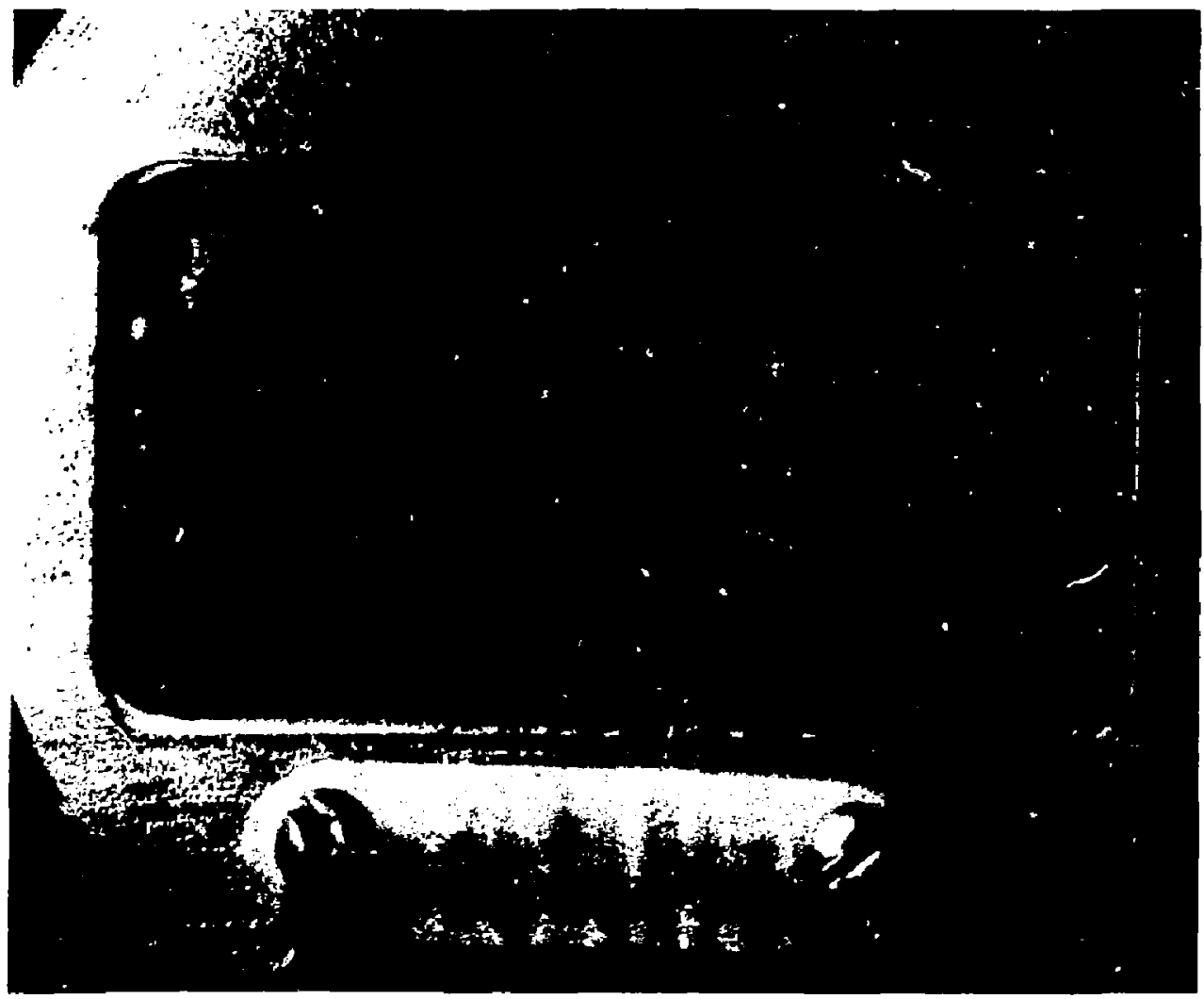

Figure 14I. Beryllium window enlarged $6 \mathrm{X}$ showing 0.001 -in. thermocouple wires laser welded to the back surface of Be foil. Thermocouple TC- 4 is mounted 6.5 mom from center and thermocouple TC-5 is mounted directly in the center that corresponds to the peak laser-impinged flux on the front surface. 


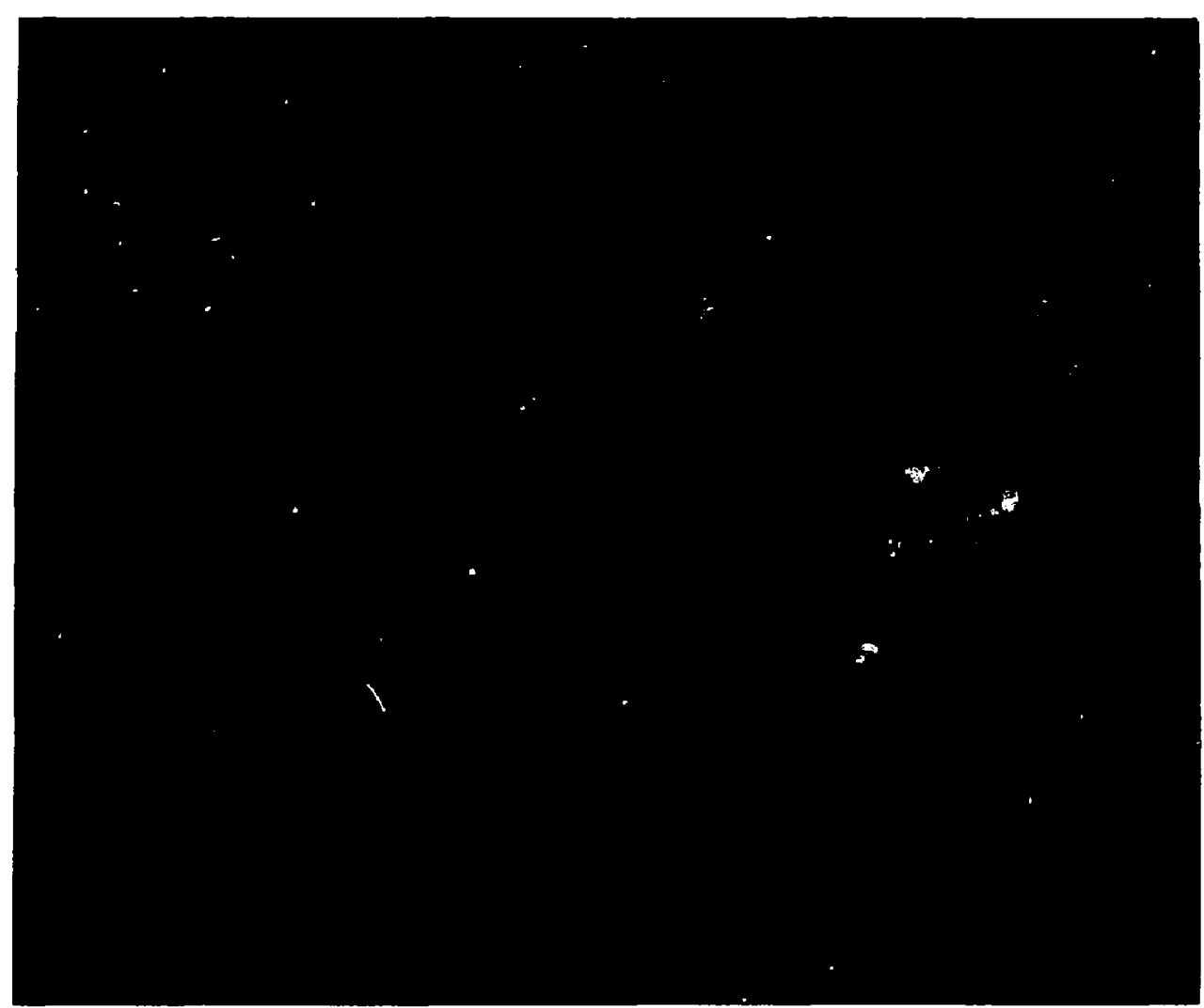

Figure 14J. Beryllium window $2 \mathrm{~A}$ showing $300 \mathrm{x}$ polished photomicrograph section of the thermocouple spot welded to the back Be surface. A good joint was obtained giving confidence to the measured thermocouple temperature readings. 
Table 4. Detailed beryllium test data for windows 1, 2A, and 2B.

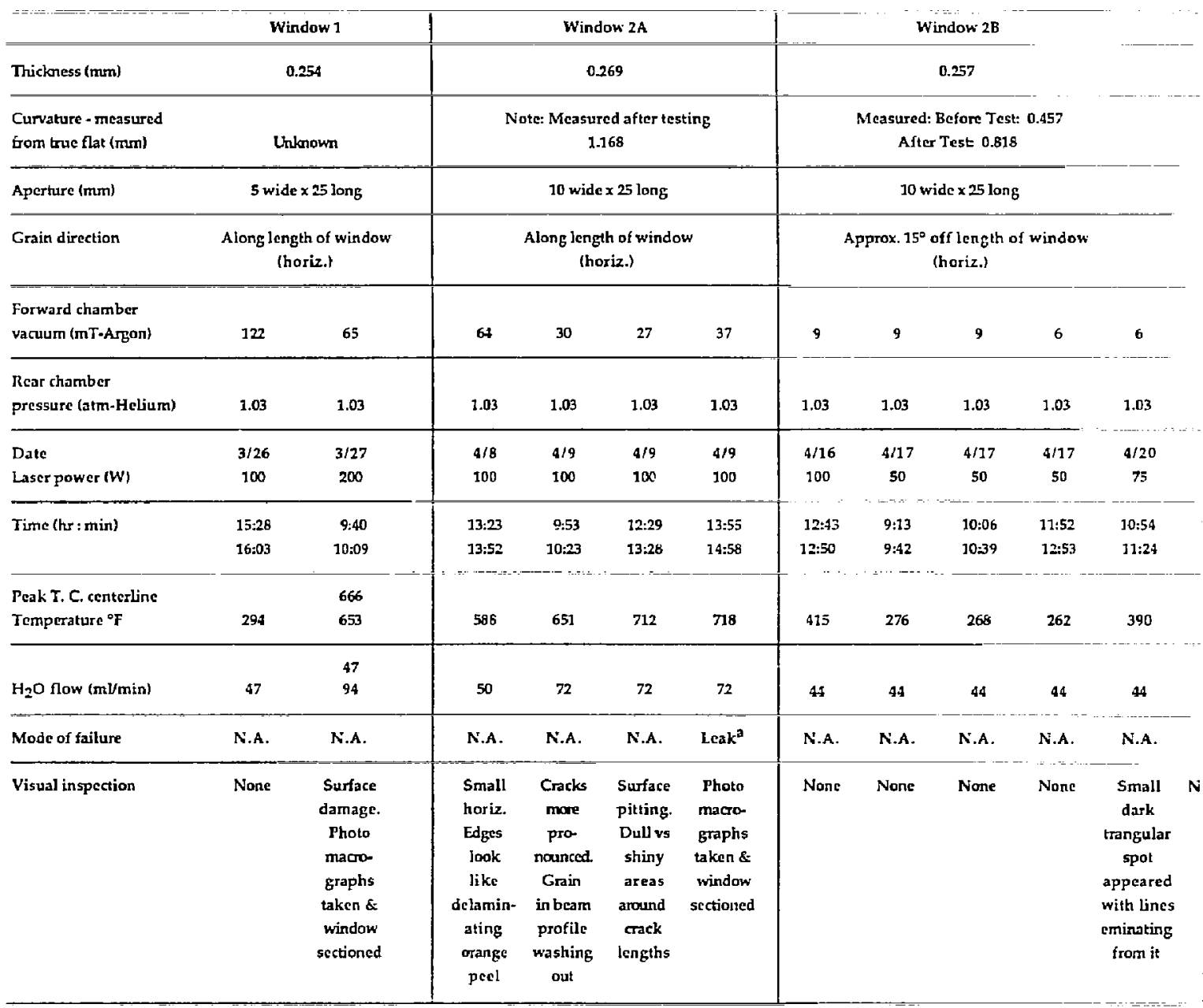

a Upon cooldown leak developed almost immediately a'ter laser shut-off (20 $\mu \mathrm{m}$ lcak). 


\begin{tabular}{|c|c|c|c|c|c|c|c|c|c|c|c|c|c|c|}
\hline 6 & 6 & 6 & 6 & 6 & 6 & 6 & 4 & 4 & 7 & 4 & 5 & i to 7 & 4107 & 4 to 7 \\
\hline 1.03 & 1.03 & 1.03 & 1.03 & 1.03 & 1.03 & 1.03 & 1.03 & 1.03 & 1.03 & 1.83 & 3.03 & 1.03 & 1.03 & 1.03 \\
\hline $4 / 17$ & $4 / 20$ & $4: 20$ & $4 / 23$ & $4 / 23$ & $4 / 21$ & $4 / 21$ & $4 / 21$ & $4 / 21$ & $4 / 21$ & $4 / 21$ & $\$ / 22$ & $4 / 22$ & $4 / 22$ & $4 / 22$ \\
\hline so & $7:$ & 75 & $7 \overline{5}$ & 75 & 67.5 & 67.5 & B7.5 & 87.5 & 67.5 & 87.5 & 87.5 & 87.5 & B?.5 & 87.5 \\
\hline i1:52 & $10: 54$ & $14: 20$ & $8: 58$ & $9: 27$ & 10:15 & 10:55 & 11.35 & $1: 36$ & $13: 20$ & $14: 0 ?$ & $8: 16$ & $8: 55$ & 10:01 & $13: 20$ \\
\hline 12:53 & $11: 24$ & $14: 50$ & 9:16 & 10:00 & 10:45 & 11:25 & 12:05 & 2:05 & $13: 50$ & $14: 37$ & $8: 46$ & 9.55 & $10: 31$ & $24: 20$ \\
\hline 262 & 390 & $\begin{array}{l}490 \\
393\end{array}$ & 363 & 378 & 437 & 432 & 431 & 430 & 425 & 435 & 438 & 442 & 439 & 446 \\
\hline 44 & 41 & 44 & 96 & 50 & 50 & 50 & 50 & 50 & 50 & 50 & 50 & 50 & 50 & 50 \\
\hline N.A. & N.A. & N.A. & N.A. & N.A. & N.A. & N.A. & N.A & N.A. & N.A. & N.A. & N.A. & N.A. & N.A. & N.A. \\
\hline None & $\begin{array}{l}\text { Small } \\
\text { dark } \\
\text { trangular } \\
\text { spot } \\
\text { appeased } \\
\text { with lines } \\
\text { eminating } \\
\text { tram i! }\end{array}$ & $\begin{array}{l}\text { Nothing } \\
\text { mare }\end{array}$ & Same & $\begin{array}{c}\text { No } \\
\text { change }\end{array}$ & $\begin{array}{l}\text { Maybe } \\
\text { more } \\
\text { grain } \\
\text { distinc- } \\
\text { tion. }\end{array}$ & $\begin{array}{l}\text { Rolling } \\
\text { grain } \\
\text { in } \\
\text { laser } \\
\text { bram } \\
\text { foot } \\
\text { print } \\
40-50 \% \\
\text { visiblc }\end{array}$ & $\begin{array}{l}\text { Mios } \\
\text { cracking } \\
2 X \& 3 X\end{array}$ & $\begin{array}{l}\text { Cracks } \\
\text { arc } \\
\text { darker }\end{array}$ & $\begin{array}{c}\text { No } \\
\text { change }\end{array}$ & $\begin{array}{l}\text { Crarks } \\
\text { are } \\
\text { getting } \\
\text { more } \\
\text { defin- } \\
\text { tion and } \\
\text { clarity }\end{array}$ & $\begin{array}{l}\text { Cracks } \\
\text { are } \\
\text { extend- } \\
\text { ing left } \\
\text { and } \\
\text { right of } \\
\text { beam } \\
\text { center } \\
\text { line }\end{array}$ & $\begin{array}{c}\text { No } \\
\text { change }\end{array}$ & $\begin{array}{c}\text { No } \\
\text { changc }\end{array}$ & $\begin{array}{l}\text { Photo } \\
\text { maco } \\
\text { graphs } \\
\text { taken \& } \\
\text { window } \\
\text { sectioned. }\end{array}$ \\
\hline
\end{tabular}


average thermal gradient from the offset thermocouple to the Be-copper interface $6 \mathrm{~mm}$ horizontally on the long window axis is calculated at $23.5^{\circ} \mathrm{C} / \mathrm{mm}$ for window 2A. Thermal gradient along the short axis from center thermocouple to Be/copper interface is $70^{\circ} \mathrm{C} / \mathrm{mm}$. The corresponding laser bean power gradients derived from the maximum slopes of the measured power distributions in Figs. 12C and 12D are $135 \mathrm{~W} / \mathrm{mm}$ vertically and $2.3 \mathrm{~W} / \mathrm{mm}$ horizontally.

The Be window accommodates the large thermal/mechanical stresses by growing/stretching. Pretest/posttest measurements show approximately $78 \%$ vertical curvature growth of window $2 B$ at its center. A crack along the long axis of window $2 A$ was first observed after the first 30 -min run just below the beam illumination profile where the thermal gradient was the greatest. Window failure happened immediately after beam shutdown after three hours of running or approximately 1,000,000 pulses (two runs at $30 \mathrm{~min}$ and two runs at $60 \mathrm{~min}$ ) and subsequent cooling. Failure was noted by the rise in pressure on the vacuum side of the window. Although horizontal cracks were observed before failure, inspection af ter failure revealed a small vertical crack on the front and rear surface of the window. None of the horizonta? cracks appeared on the rear of the window.

Scanning electron microscope (SEM) photographs and micrographs (figure series $13 \mathrm{~A}-\mathrm{E}$ and $14 \mathrm{~A}-\mathrm{J}$ ) show cross sections of the crack topography. The Be beneath the beam pattern shows an elevated temperature quasi-cleavage failure, while just outside the material failed by intergranular cleavage.

\section{RELATING LASER HEATING TO SYNCHROTRON RADIATION HEATING}

OF THE BERYLLIUM WINDOWS

In actual operating conditions the Be windows are exposed to synchrotron radiation that heats the window volumetrically. Laser irradiation heats only the surface. However, we can relate our results to actual operating conditions by analyzing how the heat flows from the beryllium to the copper heat sink. The materlal property of the beryliium that relates how transient heat is conducted from either heated area to the sink is called the thermal diffusivity. Thermal diffusivity is equal to the material's thermal conductivity divided by the product of its density and specific heat. For the laser-heated beryllium window, the time required for the unilluminated back surface to reach half of the maximum temperature rise was calculated to be approximately 2 to $4 \mathrm{~ms}$ as compared with the average lager pulse width of 
$1.2 \mathrm{~ms}$. From the characteristic thermel response times involved, the window experfenced close to steady-state thermal input conditions, as it does in the synchrotron line.

The maximum temperature recorded on the back side was $381^{\circ} \mathrm{C}$. Front surface temperatures can only be 10 to 20 degrees higher because of the high thermal conductivity of the beryllium and the short heat transfer distance. However, some of the surface grains on the front surface of the Be foil reached higher temperatures, even approaching the melting point as they were separated from the parent material by microcracking. Examples are evident in the SEMs and photomicrographs.

Window $2 A$ 's stress cracking was first observed to occur after the first ha1f hour exposure (with $85 \mathrm{~W}$ Impinging it) at approximately 180,000 pulses. Fallure occurred 2-1/2 hours (approximately one million laser pulses) later at the same beam settings. Average beam density was $3 \mathrm{H} / \mathrm{mm}^{2}$ with a peak center density of $5 \mathrm{w} / \mathrm{mm}^{2}$. SEM photographs indicate subgranular melting, but metallography macrographs do not reveal any change in grain size, although the heat-affected zone of the second window shows a finer surface structure on the crack surface.

\section{CONCLUSIONS}

An experimental study to investigate thermal-induced damage to SSRL-designed beryllium foil windows was performed at LLNL'B Laser Welding Research Facility. The primary goal of this study was to determine the threshold at which thermal-stress-induced damage occura in these commonly used vacuum barriers. An Nd:Yag pulsed laser with cylindrical optics and a carefully designed test cell provided a test environment that closely resembles the actual beamline conditions at SSRL. Tests performed on two beryllium window geometries, with different vertical aperture dimensions but equal foil thicknesses of $0.254 \mathrm{~mm}$, resulted in two focused total-powex thresholds at which incipient damage was determined. For a beam spot size simflar to that of the Beamline-X Wiggler Line, onset of surface damage for a 5-m by $25-m$ aperture window was observed at $170 \mathrm{~W}$ after 174,000 laser pulses (1.2-ms pulse at $100 \mathrm{pps}$ ).

A second window with double the vertical aperture dimension (10 $\mathrm{mm}$ by 25 $\mathrm{mm}$ ) was observed to have surface cracking after 180,000 1aser pulses with $85 \mathrm{~W}$ impinging 1 ts front surface. Failure occurred 2-1/2 hours (approximately one 
million laser pulses) later at the same $85 \mathrm{~W}$ setting. Another window of the same type (10 mm by $25 \mathrm{~mm}$ ) received $2,160,000$ laser pulses at $74.4 \mathrm{~W} \mathrm{with}$ subsequent metallographic sectioning revealing no signs of through-thickness damage. Comparison of windows with equal foil thicknesses and aperture dimensions has effectively identified the peak heat flux limit, 3 to 5 $W / \mathrm{mm}^{2}$, for incipient failure. The existing SSRL thermal flux operational 1 imit for all Be windows is $3.75 \mathrm{w} / \mathrm{mm}$. We observed damage at $3.6 \mathrm{~W} / \mathrm{mm}(5 \mathrm{~W} / \mathrm{mm}$ peak averaged over a 14-min beam length) for a 10-mm by 25-mm aperture. Therefore the existing limit should not be exceeded until an exact undergtanding of the wiggler beamline In aitu window temperatures are measured under actual operating conditions.

The data show that halving the aperture's vertical dimension allows doubling the total incident power for equivalent onsets of thermal-induced damage. Future window designs should decrease the vertical aperture dimension as much as possible.

FUTURE STUDIES

To increase the quantitative understanding of window failure, future work will include in-situ temperature measurement under actual beam operating conditions.

Future studies should include 2-D and 3-D thermal stress analysis of the above results combined with other possible window geometries and loadings. These studies should include the nonisotropic material properties of the Be foil material.

Also, a atudy should be directed at predicting the fatigue life of these windows, since they experlence daily temperature cycles. Surface cracks both from manufacturing and thermally induced will play a key role in the failure of these windows.

\section{ACKNOWLEDGMIENTS}

We wigh to thank several members of the LWN Mechanical Engineering Department taff for their valuable assistance in the Be Window Damage Study. They include MFED's Laser Welding Facility operators: Calvin Anglin, Mark Gauthier, James Murchle, and Carl Westrich, all of whom made significant contributions in assembly, implementation, calibration, and operation, along 
with many very useful suggestions for Improving the experiment. James Ferreira provided metallurgical support during experimental runs. Allen Lingenfelter provided the manpower and facility to perform the experimental part of this study. William Goodman provided the original design concept for the test cell, which was okillfully fabricated and assembled by Albert Knabe. John Lieczke and Gregory Blanchini provided ancillary equipment. We also wish to thank members of the LLNL Chemistry and Materials Science Department for their assistance. Sam Diglallonardo and Robert Meisenheimer generated metallurgical data. Interpretation was provided by Fred Fulcon and James Banafee.

Glenn Tirsell provided interpretations of expected beam thermal profiles for Beamline-X as well as guidance on physics objectives. Satish Kulkarni gave all of us essential guidance and direction to achieve success in this study. We wish to thank Car1 Poppe for his support. We also appreciate the encouragement of $A$. Bienengtock and $\mathrm{B}$. Winnick of SSRL. 